Essays

\title{
CONGRESSIONAL FACTFINDING AND THE SCOPE OF JUDICIAL REVIEW: A PRELIMINARY ANALYSIS
}

\author{
NEAL DEVINS $\dagger$
}

\section{INTRODUCTION}

Supreme Court decisionmaking treats the line separating law from fact as consequential, often outcome-determinative. Court decisions do not even hint at the possibility that the Court's choice of whether it should create fact-dependent standards of review or, alternatively, fact-insensitive rules is a by-product of exogenous variables, including the Justices' views on congressional factfinding. Rather, the Court speaks in platitudes about how "say[ing] what the law is" is at the core of Article III. In contrast, the power to find facts, while not irrelevant to the exercise of judicial authority, ${ }^{1}$ is not considered central to the judicial function. ${ }^{2}$ Indeed, pointing to Congress's "role of weighing conflicting evidence in the legislative process," ${ }^{3}$ the Court

Copyright (C 2001 by Neal Devins.

$\dagger$ Goodrich Professor of Law and Lecturer in Public Policy, College of William \& Mary. Thanks to Collin Cox and the Duke Law Journal for organizing this symposium. Thanks also to participants at faculty workshops at William and Mary and the University of San Diego for commenting on a preliminary version of this Essay. Thanks, finally, to John Duffy, Lou Fisher, Phil Frickey, Barry Friedman, Alan Meese, John McGinnis, Jaime Murray, Ed Rubin, and Charles Tiefer for their helpful comments.

1. See, e.g., Sable Communications, Inc. v. FCC, 492 U.S. 115, 129 (1989) (noting that the presence of legislative findings "would not foreclose [the Court's] independent judgment" of pertinent constitutional facts).

2. Bi-Metallic Inv. Co. v. State Bd. of Equalization, 239 U.S. 441, 445-46 (1915) (holding that not every person affected by a broad administrative decision is entitled to a direct voice in its adoption).

3. Turner Broad. Sys., Inc. v. FCC, 520 U.S. 180, 199 (1997). For a useful criticism of Turner Broadcasting, see Note, Deference to Legislative Fact Determinations in First Amendment Cases After Turner Broadcasting, 111 HARV. L. REV. 2312, 2329 (1998) (criticizing the "patchwork doctrine for determining the level of deference due to legislative fact determinations" established by the case). 
treats the separation of powers as demanding a de minimis judicial role in questioning the accuracy of such findings. ${ }^{4}$

Part I of this Essay challenges this longstanding assumption, arguing that the law-fact divide is a shibboleth, something that the Court invokes to justify a conclusion about whether it or Congress should settle an issue, not something with independent analytical force. Correspondingly, this Essay suggests that when employing factdependent reasoning, the Court is speaking more of its agreement with Congress on the merits than anything else.

Part II casts doubt on a related assumption, namely, that as a matter of comparative institutional competence, the Court is better at sorting out the law and legislators are better equipped to get the facts right. In particular, while Congress has superior factfinding capacities, it often lacks the institutional incentives to take factfinding seriously.

By calling attention to how problematic and difficult it is for the Court to navigate the law-fact divide, this Essay is a first step in redirecting attention to the real world problems of drawing sharp and discernible lines separating the judicial and legislative functions. Part III ventures beyond these positive claims and tackles the question of how the Supreme Court ought to take into account Congress's interest in getting the facts right. Through the use of case studies, Part III offers a preliminary assessment of the ways in which the Court can sort out whether Congress has the proper incentives to take factfinding seriously. In so doing, Part III also draws attention to a paradox in constitutional decisionmaking - the Court's employment of open-ended, fact-dependent standards often make it difficult for the Court to take a hard look at congressional factfinding. Specifically, because of limits on its own factfinding, the Court cannot disavow traditionalist assumptions (embraced in Court decisionmaking) about both Con-

4. E.g., Turner Broad. Sys., 520 U.S. at 195 ("We owe Congress' findings deference in part because the institution is far better equipped than the judiciary to amass and evaluate the vast amounts of data bearing upon legislative questions.") (quotations omitted); Metro Broad., Inc. v. FCC, 497 U.S. 547, 572 (1990) ("The 'special attribute [of Congress] as a legislative body lies in its broader mission to investigate and consider all facts and opinions that may be relevant to the resolution of an issue."”) (quoting Fullilove v. Klutznick, 448 U.S. 448, $502-03$ (1980)); Schweiker v. Chilicky, 487 U.S. 412, 425 (1988) ("Congressional competence at balancing governmental efficiency and the rights of [individuals] is no more questionable in the social welfare context than it is in the civil service context.") (quotations omitted). For a competing interpretation of recent Court precedents, see A. Christopher Bryant \& Timothy J. Simeone, Remanding to Congress: The Supreme Court's New "On the Record" Constitutional Review of Federal Statutes, 86 CORNELL L. REV. 328, 396 (2001) ("[T] he Court's new approach [requiring an extensive legislative record to justify legislation] is simply inconsistent with the political realities of congressional factfinding."); see also infra note 18 (critiquing Bryant and Simeone). 
gress's comparative advantage in factfinding and Congress's authority, under the separation of powers, to sort out the facts underlying its handiwork. Consequently, by describing an issue as one of fact, not law, the Court, in effect, is saying that Congress is the branch best positioned to decide the matter.

This Essay aims at advancing not only a system of empirically informed constitutional jurisprudence 5 but also a system that allows Congress, when circumstances warrant, to play a decisive role in the shaping of constitutional values. In particular, rather than sort through the legitimacy of courts "making policy" through the application of fact-dependent balancing tests, this Essay is intended to push the Supreme Court to embrace standards of review that take into account the comparative institutional strengths and weaknesses of both Congress and the courts. Sometimes these standards will favor the government (when Congress is a reliable factfinder); sometimes these standards will limit governmental action (when, for example, congressional factfinding is little more than a recitation of special-interest preferences). ${ }^{6}$

By highlighting the contaminating impact of special interests on congressional factfinding, moreover, this Essay addresses one of the fundamental questions in constitutional law, that is, the need to check Congress from acting on behalf of special interests, to the exclusion of the public interest. ${ }^{7}$ By recommending that the Supreme Court deploy standards of review that take Congress's interest in factfinding into account, this Essay calls for the Court to check Congress when the

5. For recent commentary on the role that facts should play in constitutional decisionmaking, see Richard A. Posner, Against Constitutional Theory, 73 N.Y.U. L. REV. 1, 21 (1998) (arguing that "the lack of an empirical footing" is the "Achilles heel of constitutional law"); see also Deborah Jones Merritt, Constitutional Fact and Theory: A Response to Chief Judge Posner, 97 MiCH. L. REV. 1287, 1291-93 (1999) (arguing that empirical studies "can influence” but "can't resolve constitutional issues").

6. Needless to say, factfinding is not the sole variable in judicial decisionmaking. The Justices will also take into account theories of interpretation, stare decisis, the political climate, and much more. At the same time, the quality of congressional factfinding is certainly relevant, and, as such, it is useful to think of the ways in which the Court can take factfinding into account when crafting standards of review.

7. Recognizing that interest groups "have peculiar power to use the government to expropriate resources for themselves," for example, constitutional structures seek to protect against special-interest rent-seeking. John O. McGinnis, The Original Constitution and Its Decline: A Public Choice Perspective, 21 HaRv. J.L. \& PUB. PoL'y 195, 197 (1997). In linking my project to the question of special-interest capture, I am not suggesting that courts should defer to Congress when legislative uninterest in factfinding is tied to popular support for a law. See infra notes 107-18 (highlighting populist support for federalism-related initiatives). While politically popular lawmaking may serve the public interest, an empirically minded Court cares most about Congress's interest in getting the facts right. See infra note 177. 
risk of special-interest capture seems especially significant. ${ }^{8}$ More to the point, because of the difficulties of the Court second-guessing legislative factfinding, this Essay sends a cautionary note to Justices inclined to make use of fact-dependent standards in upholding congressional decisionmaking.

\section{THE ILLUSORY FACT-LAW DISTINCTION}

Is the Court's characterization of an issue as being one of law or one of fact driven by a desire to reach a particular outcome? Alternatively, is the law-fact divide a by-product of the very real differences between the institutional authority and competence of the Court and Congress? ${ }^{10}$ Answers to these questions lie in the opinions and institutional incentives of the Court.

To start, Supreme Court opinions suggest that the line separating law from facts, if not artificial, is indeterminate. Consider, for example, the Court's recent decisions in Dickerson v. United States (rejecting Congress's efforts to undo the Miranda warning $)^{11}$ and United States $v$. Morrison (invalidating the Violence Against Women Act). ${ }^{12}$ In both cases, the Court sidestepped the question of whether the factual premises underlying Congress's handiwork were correct; ${ }^{13}$ in-

8. In contrast, when powerful special interests combat each other, the public interest is served, and, as such, there is less reason to check Congress. For an analogous argument, see generally Daniel A. Farber, State Regulation and the Dormant Commerce Clause, 3 Const. COMMENT. 395 (1986) (arguing that out-of-state business interests are almost always able to protect themselves at both the state and federal levels, and, consequently, the Supreme Court should limit the scope of its dormant Commerce Clause decisionmaking).

9. In this way, an empirically informed jurisprudence is appealing both to Justices interested in the correctness of Congress's underlying factual premises and to Justices whose interpretive theories are grounded in the belief that the Constitution is principally a bulwark against special-interest capture.

10. In researching this question, I greatly benefited from Saul M. Pilchen, Politics v. The Cloister: Deciding When the Supreme Court Should Defer to Congressional Factfinding Under the Post-Civil War Amendments, 59 Notre Dame L. Rev. 337 (1984) (criticizing the factfinding theory used to justify enhanced congressional power under the post-Civil War amendments).

11. 530 U.S. 428 (2000).

12. 529 U.S. 598 (2000).

13. The factual finding in Dickerson concerned whether or not custodial interrogations are inherently coercive and intimidating. The Miranda Court said yes. Miranda v. Arizona, 384 U.S. 436, 533 (1966). Congress, responding to Miranda, said no. S. REP. No. 90-1097, at 54-55 (1968). For further discussion, see generally Robert A. Burt, Miranda and Title II: A Morganatic Marriage, 1969 Sup. CT. REV. 81, 123-32; Archibald Cox, The Role of Congress in Constitutional Determinations, 40 U. CIN. L. REV. 199, 249-50 (1971) (discussing the Supreme Court's refusal to set aside legislative findings of constitutional fact in a wide variety of situations). Morrison likewise centered on the relevance of "a voluminous" record, finding, among other things, that domestic violence and sexual assault reduced the mobility of women employees as well as "their production and consumption of goods shipped in interstate commerce." Morrison, 529 U.S. at 
stead, the Court concluded that, as a matter of law, Congress's factual inquiry was beside the point. ${ }^{14}$ The dissenting opinions in both Morrison and Dickerson, however, made use of quite different legal standards - standards by which congressional factfinding was anything but irrelevant. ${ }^{15}$ Indeed, the Morrison dissent is replete both with approving references to "the mountain of data assembled by Congress" and paeans to "Congress, whose institutional capacity for gathering evidence and taking testimony far exceeds" that of the Court. ${ }^{16}$

Another example of this phenomenon is the rights-remedy distinction that the Court now utilizes in assessing Congress's power to enforce the Fourteenth Amendment. When overturning the Religious Freedom Restoration Act (RFRA), the Court, in City of Boerne v. Flores, drew a sharp line between Congress's power to "remed[y] constitutional violations" and the Court's power to set forth the meaning of a constitutional right and thereby to "say what the law is." 17 This standard, however, is indeterminate; when applying it, the Justices often disagree about whether Congress's action speaks to rights (so that factfinding is not particularly relevant) or remedies (where factfinding is often dispositive). ${ }^{18}$ For instance, in rulings that

635-36 (Souter, J., dissenting) (quoting S. REP. NO. 103-138, at 54 (1994)). Congress also found that the annual cost of domestic violence to the economy was $\$ 5$ to $\$ 10$ billion a year. Id. at 635 (quoting S. REP. NO. 103-138, at 41 (1994)). In challenging the constitutionality of the statute, however, Morrison argued that "[t]he only 'findings' concerning gender-based, animusmotivated violence are in the final Conference Report, findings so broad and conclusory that they ... add virtually nothing to the record." Brief of Respondent Antonio J. Morrison at 24, U.S. v. Morrison, 529 U.S. 598 (2000).

14. Dickerson, 530 U.S. at 431-33; Morrison, 529 U.S. at 684.

15. Dickerson, 530 U.S. at 431 (Scalia, J., dissenting) (rejecting "the power of the Supreme Court to write a prophylactic, extraconstitutional Constitution, binding on Congress and the States"); Morrison, 529 U.S. at 683 (Souter, J., dissenting) ("Congress has the power to legislate with regard to activity that, in the aggregate, has a substantial effect on interstate commerce.").

16. Morrison, 529 U.S. at 683 (Souter, J., dissenting); see also id. at 684-85 (Souter, J., dissenting) (detailing some of the evidence before Congress).

17. 521 U.S. 507, 518-19 (1997). Consequently, although the RFRA contained findings that intentional discrimination against religion can only be prevented by treating governmental conduct that burdens religion as constitutionally suspect, the Court concluded that Congress's interest was altering, not enforcing, the Free Exercise Clause. Id. at 519. For an excellent treatment of this topic, see generally Daryl J. Levinson, Rights Essentialism and Remedial Equilibrium, 99 COLUM. L. REV. 857 (1999) (addressing the "rights/remedies" distinction in constitutional law as a means to protect the "privileged status of constitutional rights").

18. This formula treats the law-fact divide as consequential. When Congress is remedying discrimination (a decision grounded in hard facts), Congress wins; when Congress is seeking to redefine a constitutional right (a decision about legal norms), it loses. For this reason, claims that the Rehnquist Court is disavowing traditionalist deference to legislative factfinding seem somewhat overblown. See Bryant \& Simeone, supra note 4, at 369-89 (criticizing at length this "new approach" of the Rehnquist Court). No doubt, by "aggressive[1y]" examining "the formal legislative record" to see if it adequately supports congressional action, the Rehnquist Court (on 
Congress could not extend either age discrimination or disability rights protections to state workers, the Court divided five to four on whether these cases were about rights (law) or remedies (facts). ${ }^{19}$

Morrison, Dickerson, and Flores are hardly unusual. The Justices frequently squabble over the appropriate standard of review to apply and, with it, the types of facts (if any) that are relevant to their decisionmaking. ${ }^{20}$ Whether characterizing a matter as one of law or fact is

Section 5 matters) is willing to second-guess congressional factfinding. Id. at 330. But the Court is undertaking this enterprise as part and parcel of its power to "say what the law is"; in particular, if the Court concludes that Congress has not demonstrated that the states have acted unconstitutionally (the factual predicate for a Section 5 remedy), the Justices see Congress's action as interfering with the Court's power to define constitutional rights. For an empirically minded Court, as I will argue in Part III.B of this Essay, this formula allows it to sort out the seriousness of congressional factfinding without departing from traditionalist norms associated with the law-fact divide. See infra notes 101-33 and accompanying text.

19. Bd. of Trustees of the Univ. of Ala. v. Garrett, 121 S. Ct. 955, 967-68 (2000) (exempting states from civil suits under the Americans with Disabilities Act, and exposing a disagreement between the majority and the dissent over whether Congress made sufficient findings to show that the states had engaged in pervasive unconstitutional discrimination against the disabled); Kimel v. Fla. Bd. of Regents, 528 U.S. 62, 91 (2000) (concluding that Congress "had no reason to believe that broad prophylactic legislation was necessary" to extend age discrimination protections to state workers). In both cases, the Court took aim at Congress. In Kimel, the majority concluded that "Congress' 1974 extension of the Act to the States was an unwarranted response to a perhaps inconsequential problem." Id. at 89. In Garrett, according to the dissent, the majority downplayed the fact that "hundreds of examples of discrimination by state and local governments ... were submitted to [a congressional] task force" as part of Congress's factfinding efforts. Garrett, 121 S. Ct. at 972 (Breyer, J., dissenting). Instead, the majority-noting that Congress made no formal findings of "a pattern of unconstitutional behavior by the States"downplayed this evidence (describing it as "unexamined, anecdotal accounts of 'adverse, disparate treatment by state officials"”). Id. at 966 (quoting Garrett, 121 S. Ct. at 970 (Breyer, J., dissenting)).

By placing the onus on Congress to demonstrate that it is remedying unconstitutional governmental action, the rights-remedy distinction enables the Court to declare a matter as a "question of law" when it disapproves of congressional factfinding. See supra note 18; infra Part III.B. Another recent example of this phenomenon is Florida Prepaid Postsecondary Education Expense Board v. College Savings Bank, 527 U.S. 627 (1999). In rejecting legislative efforts to protect patent rights by abrogating state sovereign immunity, a majority of the Justices concluded that Congress did not identify a "pattern of patent infringement by the States, let alone a pattern of constitutional violations." Id. at 640. Consequently, these Justices rejected efforts to depict the Patent Remedy Act as a remedy to unconstitutional state conduct. In contrast, four dissenting Justices, after detailing Congress's extensive factfinding on the issue, concluded that "Congress had sufficient evidence of due process violations, whether actual or potential, to meet the requirement we expressed in City of Boerne that Congress can act under $\S 5$ only to 'remedy or prevent unconstitutional actions." Id. at 660 (quoting City of Boerne, 521 U.S. at 519) (Stevens, J., dissenting); see also David Cole, The Value of Seeing Things Differently: Boerne v. Flores and Congressional Enforcement of the Bill of Rights, 1997 SUP. CT. REV. 31, 67-69 (calling attention to the difficulty of distinguishing a right from a remedy); Cox, supra note 13, at 233-34 (calling attention to how it is that "questions of fact" for one Justice may be seen by another Justice as a value-laden process of "striking a balance between incommensurate interests").

20. E.g., United States v. Lopez, 514 U.S. 549, 562 (1995) (employing different legal standards, between the majority and dissent, in assessing Congress's Commerce Clause power, and therefore disagreeing over the relevance of the fact that "[n]either the statute nor its legislative 
simply "a conclusion ... that one branch of government rather than another should make the decision in question," 21 it is undoubtedly true that a Justice's views on the merits and her views on whether the case turns on law or facts are often one and the same. Justices sympathetic to the goals of a particular statute, if not Congress itself, typically see the issue before them as one of fact; Justices skeptical of Congress, in contrast, are more apt to see the issue as one of law.

This practice will likely continue. The Court is unlikely to depart from the traditionalist view that the separation of powers places the finding of social facts squarely within the realm of the lawmaking power. ${ }^{22}$ Furthermore, lacking the power to appropriate funds or command the military, the Court understands that its decisions must garner public acceptance. ${ }^{23}$ For these reasons, the Justices can ill afford to act as super-lawmakers, striking down legislation whenever their views of the facts vary from Congress's ${ }^{24}$ instead, the Justices are on firmer footing by grounding their decisions (especially those striking down acts of Congress) in legal interpretations. It is thus undoubtedly the case that unless and until the nation is convinced that

history contains findings regarding the effects upon interstate commerce of gun possession in a school zone") (quotations omitted); Metro Broad., Inc. v. FCC, 497 U.S. 547, 572, 579, 629 (1990) (questioning whether "[e]ven the most express and lavishly documented congressional declaration" on affirmative action was sufficient under intermediate or strict scrutiny review, or, alternatively, whether the Court "must give great weight" to legislative findings thereby allowing Congress to "legislate without compiling" a detailed record); see also Pilchen, supra note 10, at 380-96 (detailing other examples).

21. Pilchen, supra note 10, at 396-97. Nearly seventy years ago, Stanley Surrey-then a young attorney working for the National Labor Relations Board-likewise suggested that the Court's view of good public policy would play an instrumental role in its characterization of an issue as one of fact or law. Specifically, in a memo assessing the constitutionality of the National Labor Relations Act, Surrey emphasized that the Court's willingness to tie its decisionmaking to congressional findings is, ultimately, a question of "how radical a departure from existing constitutional theory and generally accepted forms of legislative control the Court deems the" Act to be. Philip P. Frickey, The Fool on the Hill: Congressional Findings, Constitutional Adjudication, and United States v. Lopez, 46 CASE W. RES. L. REV. 695, 699 (1996) (quoting Surrey's memorandum).

22. See supra note 4 and accompanying text; see also Bi-Metallic Inv. Co. v. State Bd. of Equalization, 239 U.S. 441, 445 (1915) (holding that the Constitution does not demand due process in lawmaking, for "[w]here a rule of conduct applies to more than a few people it is impracticable that every one should have a direct voice in its adoption").

23. Tom R. Tyler \& Gregory Mitchell, Legitimacy and the Empowerment of Discretionary Legal Authority: The United States Supreme Court and Abortion Rights, 43 DuKE L.J. 703, 715 (1994) (discussing the link between "public acceptance" of the Court and the Court's institutional legitimacy). Chief Justice Rehnquist has also recognized this connection between its "legitimacy" and the "people's acceptance." Planned Parenthood v. Casey, 505 U.S. 833, 965-66 (1992) (Rehnquist, J., concurring).

24. I should add that the President is implicated in this as well, for the President signs bills into law. 
the Supreme Court is a better factfinder than Congress, the Court places itself at peril by declaring that Congress got the facts, not the law, wrong. Where facts should come into play, as I have suggested above, is in the selection of standards of review.

For these very reasons, the Justices should act cautiously before embracing fact-dependent standards of review. These standards, by constraining the Court's power to second-guess legislative decisionmaking, give Congress the upper hand. For example, following its 1937 embrace of the fact-dependent "affecting commerce" standard, the Court regularly looked to legislative findings establishing a link between New Deal initiatives and interstate commerce. ${ }^{25}$ As a result, the Court has been extremely deferential to Congress; it has only once cast doubt on legislative factfinding in its Commerce Clause decisionmaking. ${ }^{26}$ In other words, by choosing a fact-dependent standard of review, the Court severely limited its ability to check Congress.

While the Court should carefully weigh the risks of adopting factdependent standards, it is unclear to what extent the Court's attitudes towards congressional factfinding affect the Justices' views of whether it should employ fact-dependent standards of review. No doubt, just as theories of interpretation, ideology, and fear of elected government reprisal temper the Court's decisionmaking, "perceptions about social facts regularly tip the balance between competing constitutional rights or affect the definition of legitimate state interests and individual rights." 27

But in sorting out these social facts, does the Court pay close attention to the seriousness by which Congress finds facts? The Court, while making use of legislative findings in its decisions, does not demand that Congress find facts, hold hearings, or otherwise employ procedures designed to improve the quality of its factfinding. ${ }^{28}$ At the

25. See infra notes $125-28$ and accompanying text.

26. United States v. Lopez, 514 U.S. 549, 563 (1995) (finding that "to the extent that congressional findings would enable [the Court] to evaluate the legislative judgment that the activity in question substantially affected interstate commerce, even though no such substantial effect was visible to the naked eye, they are lacking [in Lopez]").

27. Peggy C. Davis, "There is a Book Out ...": An Analysis of Judicial Absorption of Legislative Facts, 100 HARV. L. REV. 1539, 1590 (1987) (discussing Smith v. OFFER, 431 U.S. 816 (1977), a decision whose standard of review can be directly tied to the Court's perceptions of the conflicting social science evidence presented to it); see also Kenneth Culp Davis, Facts in Lawmaking, 80 CoLUM. L. REV. 931, 935-38 (1980) (considering the use of factual data in Supreme Court decisionmaking); Nicholas S. Zeppos, Legislative History and the Interpretation of Statutes: Toward a Fact-Finding Model of Statutory Interpretation, 76 VA. L. REV. 1295, 1357 (1990) (asserting that facts "unquestionably shape the evolution of the rules themselves").

28. See Bryant \& Simeone, supra note 4, at 355-69 (considering whether heightened scru- 
same time, there is reason to doubt that the Court assumes Congress to be a reliable factfinder (so that judicial skepticism of legislative factfinding may affect the decision to characterize an issue as one of law, not fact). The Court, for example, may have seen the RFRA as little more than special-interest politics ${ }^{29}$ and the Miranda override statute as "election year symbol[ism]." " In other words, skepticism of Congress's factfinding may have been a contributing factor in explaining why the Court in both City of Boerne and Dickerson depicted the issues before them as questions of law, not fact. ${ }^{31}$

If one values an empirically informed jurisprudence, congressional attitudes toward factfinding should figure prominently in the Justices' decision to treat a question as one of law or fact. How then should the Court sort out the quality of congressional factfinding? Should the Court look to legislative history-depicting an issue as one of fact when Congress makes findings of facts, holds hearings, etc.? Should it make use of a prophylactic rule-assuming either that Congress is institutionally superior to the courts in getting the facts right or, alternatively, that Congress is captured by special interests and, consequently, is an unreliable factfinder? Any attempt at answering these questions must begin with an analysis of the comparative strengths and weaknesses of judicial and congressional factfinding.

\section{FACTFINDING IN CONGRESS AND THE COURTS}

Judicial deference to legislative factfinding is premised on the mutually reinforcing beliefs that the lawmaking process is better suited to finding social facts ${ }^{32}$ than is adjudication and that the Constitution leaves it to lawmakers, not judges, to make policy by finding social facts. By itself, however, this rationale is hardly convincing. Af-

tiny of the legislative record in constitutional cases is consistent with Supreme Court precedent and specifically discussing what the Court has required of Congress in its capacity as factfinder).

29. See infra notes $115-18$.

30. Brief of Amicus Curiae House Democratic Leadership at 5, Dickerson v. United States, 530 U.S. 428 (2000); see also Michael C. Dorf \& Barry Friedman, Shared Constitutional Interpretation, 2001 SUP. CT. REV. (forthcoming May 2001) (noting that "a Congress that wishes deference has to earn it. Section 3501 [the Miranda override statute] was hardly deserving of such respect"); Yale Kamisar, Can (Did) Congress "Overrule" Miranda?, 85 CORNELl L. REV. 883, 927 (2000) (arguing that Congress was not at all interested in working within the constitutional parameters set forth in Miranda).

31. No doubt, these decisions are also about the Court defending its institutional turf. In both cases, Congress sought to override a controversial decision of which it disapproved.

32. Social (or legislative) facts "are the recurrent patterns of behavior on which policy must be based"; adjudicative facts "are the events that have transpired between the parties to a lawsuit.” Donald L. Horowitz, THE COURTS AND SOCIAL POLICY 45 (1977). 
ter all, as Part I suggests, the law-fact distinction may be a judicial conceit-something used to prop up a conclusion about whether the Court or Congress should settle an issue. Indeed, as this part will show, it is hardly self-evident that the legislative process does a better job of uncovering social facts than does adjudication.

In sorting through whether lawmakers or courts are more apt to engage in accurate factfinding, this part will make a quick tour of the comparative strengths and weakness of the two branches, considering both institutional capacity and institutional incentives. The concern here is not so much resolving the question of which branch does a better job; rather, it is to suggest that the answer to this question is highly contextual-Congress does a better job when it has the incentive to get the facts right while the courts may do a better job when the litigants skillfully present conflicting social science data. ${ }^{33}$

\section{A. The Traditionalist's Argument: Congress Can Do It; Courts Cannot}

Congress has numerous advantages over the courts in pursuing information. Legislatures, as compared to courts, "have substantial staff, funds, time and procedures to devote to effective information gathering and sorting. ${ }^{34}$ These assets are perhaps best employed in the committee system, which allows lawmaker experts to acquire extensive knowledge on questions of interest to them. ${ }^{35}$ Armed with the power to subpoena witnesses and otherwise do what is "necessary and proper" to allow Congress to effectively act on its legislative powers, committees operate both as legislative "gatekeepers" and "policy in-

33. Courts may also do a better job of factfinding when judges are willing to assume the role of policymaker, not adjudicator. See generally MALCOLM M. FEELEY \& EDWARD L. Rubin, JUdicial POLICY MAKING AND THE MODERN STATE (1998) (analyzing policymaking as a distinct, and even legitimate, judicial function). To do so, however, may risk the courts' institutional legitimacy. Neal Devins, I Love You Big Brother, 87 CALIF. L. REV. 1283, 1285-89 (1999) (critiquing Feeley and Rubin's claim that federal courts can engage in policymaking much the same way as an administrative agency).

34. Robin Charlow, Judicial Review, Equal Protection and the Problem with Plebiscites, 79 CORNELL L. REV. 527, 578 (1994). Judges do not have investigative or research staffs. Consequently, judges may have difficulty translating scientific and other studies. They may not know the scientific method and the importance of validity, replicability, etc., to social science data. Kenneth Culp Davis, Judicial, Legislative, and Administrative Lawmaking: A Proposed Research Service for the Supreme Court, 71 MINN. L. REV. 1, 5-6 (1986).

35. See generally Christopher J. DeERING \& Steven S. SMith, CommitTees in CONGRESS (3d ed. 1997) (examining the current state of committees and committee systems in the House and Senate); Keith Krehbiel, Information and Legislative Organization (1991) (contending that Congress organizes into committees so that its members may gain expertise). 
cubators. ${ }^{, 36}$ Unconstrained by the need to decide a particular case at a particular moment in time, moreover, legislative committees may conduct hearings over a number of months, even years, before acting. Furthermore, rather than rely on party arguments and amicus filings, committees may act affirmatively_using their subpoena power to call any and all witnesses who may assist Congress in sorting out the facts. If that is not enough, committees can also seek expert advice from any one of a number of legislative support services, including the Congressional Research Service and the General Accounting Office. ${ }^{37}$

More generally, Congress is not limited by rules against ex parte communications or other prohibitions on information gathering. Instead, members of Congress and the senior staff who advise them may inform themselves by speaking with each other, "lobbyists, [other] staff, friends and constituents, by [attending] fact-finding junkets, by reviewing past legislation or even by reading a novel or watching television., ${ }^{38}$ Also, unlike the judiciary, "[t]he greater number of members [of Congress] and their varied backgrounds and experience make it virtually certain that the typical legislature will command wider knowledge and keener appreciation of current social and economic conditions than will the typical court." ${ }^{39}$ Correspondingly, the geographic diversity among lawmakers ensures that Congress will take regional differences into account when assessing the costs and benefits of proposed legislation. In these ways, Congress, a truly representative body, is better positioned to find facts than the federal judiciary, whose judges and advocates are trained in a single discipline and, for the most part, are otherwise stratified by class, ambition, and the like. ${ }^{40}$

36. Cox, supra note 13, at 209 (asserting that the subpoena power allows legislative committees to develop the "relevant data"); Daniel A. Farber \& Philip B. Frickey, Legislative Intent and Public Choice, 74 VA. L. REV. 423, 448 (1988) (arguing, contrary to Justice Scalia, that Congress's committees are involved in the details of legislation and, as such, are well aware of the contents of their reports).

37. Louis Fisher, Constitutional Interpretation by Members of Congress, 63 N.C. L. REV. 707, 730 (1985) (noting, however, that GAO lawyers are hesitant to question the constitutionality of a statute).

38. Wendy M. Rogovin, The Politics of Facts: "The Illusion of Certainty," 46 Hastings L. J. 1723, 1743 (1995).

39. Cox, supra note 13, at 209; see also MARK TUSHNET, TAKING THE CONSTITUTION AWAY FROM THE COURTS 68 (1999) (asserting that "[1]egislators in ordinary politics are [more] deeply embedded in the realities of public life" than are judges). For a competing perspective, see Michael J. MALbin, Unelected RePresentatives 247 (1980) (arguing that policy in Congress is made by "staff technocrats ... whose knowledge of the world is limited to what they learned in school or from other participants in the specialized Washington issue networks").

40. In other words, while judicial factfinding has no public anchor, elections make the Con- 
Congress's unique ability to gather and assess information, while critically important, tells only part of the story. Congress need not decide a case once and forever by issuing a decision that constrains it in subsequent decisionmaking. "Unlike judges, legislators can simultaneously address a variety of issues, thus facilitating the development of public policy that reflects a fair balance of competing interests." ${ }^{41}$ Even more significantly, Congress is not constrained by stare decisis. It can correct its mistakes in ways that the Court cannot. Specifically, Congress's legitimacy is not at all tied to whether it stands above the hurly burly of politics by adhering to precedent. Quite the contrary: Congress's legitimacy, as Frank Michelman describes it, is that the legislature is the "forum for identifying or defining [objectives], and acting towards those ends."

Courts, as compared to lawmakers, are shackled by the temporal and reactive nature of litigation. Specifically, with judges and advocates relying on precedent-based legal arguments, courts simply cannot engage in thorough cost-benefit analysis. Courts are also hamstrung in that they decide cases at a moment in time, so that a changed understanding of the underlying facts can only be corrected through a reversal. Correspondingly, judges must operate around "real time" constraints; rather than risk a backlog of cases, judges must do the best they can with the information that they have. ${ }^{43}$ For the Supreme Court, real-world limits on the number of cases it can review necessarily leave broad decisionmaking authority in the federal courts of appeal, courts that "are not national in their scope" and who may disagree over standards of review, the relevance of certain facts, and much more. ${ }^{44}$

gress representative of public views. Furthermore, to the extent that the public itself finds social facts by choosing who it elects, congressional factfinding reflects the current national view.

41. Stephen F. Ross, Legislative Enforcement of Equal Protection, 72 MINN. L. REV. 311, 327 (1987). For this very reason, Ross argues that the legislative process is well designed to "analyze the detailed and complex problem of whether a given classification can be justified despite its overbreadth or underinclusiveness." Id.

42. Frank I. Michelman, Political Markets and Community Self-Determination: Competing Judicial Models of Local Government Legitimacy, 53 IND. L.J. 145, 149 (1977). For this very reason, the Constitution (rightly or wrongly) "presumes that, absent some reason to infer antipathy, even improvident decisions will eventually be rectified by the democratic process." Vance v. Bradley, 440 U.S. 93, 97 (1979).

43. Ernest Young, Rediscovering Conservatism: Burkean Political Theory and Constitutional Interpretation, 72 N.C. L. REV. 619, 636 (1994) (noting that one shortcoming of judicial constitutional decisionmaking is that "dockets are so crowded that judges can devote little time even to critical cases").

44. Frank B. Cross, Institutions and Enforcement of the Bill of Rights, 85 CORNELL L. REV. 1529, 1549 (2000). 
Furthermore, notwithstanding amicus curiae filings, courts, including the Supreme Court, often rely on the arguments made by the parties before it. ${ }^{45}$ Thus the Court, unlike Congress, is constrained by the parties' framing of the issues. Correspondingly, the Court may "anchor" its decisionmaking on its perception of whether the parties before it are sympathetic or not. Problems may arise, however, when different parties raising identical legal issues may appear more or less sympathetic and, as such, the Court's decision may well be tied to the accident of which plaintiff presents its case to the Court. ${ }^{46}$

Making matters worse, the Justices may engage in "motivated reasoning," that is, a desire to understand the facts through the lens of prevailing social norms. ${ }^{47}$ Finally, the Justices may be animated, in part, by political ideology. As such, rather than try to get the facts right, the Justices may spin the facts to support a desired result. ${ }^{48}$ And

45. Philip B. Kurland, Toward a Political Supreme Court, 37 U. CHI. L. REV. 19, 38 (1969) (noting that the Court "lacks machinery for gathering the wide range of facts and opinions that should inform the judgment of a prime policymaker," because, among other things, it must base its decisions "on the evidence and materials brought before it by the litigants or such similar information as may be garnered by its very small staff from already existing published data"). One solution to this problem, suggested by Judge Richard Posner, would have the academy invest its energies into producing empirical studies that will help judges ferret out the factual premises that underlie legislative decisionmaking. Posner, supra note 5, at 12 . In advancing this proposal, Posner assumes that judges can identify which empirical studies, in fact, are reliable. However, limitations in staff and training, as well as ideological predispositions, cast doubt on Posner's proposal.

46. For an overview treatment of anchoring and other behavioral economics topics, see Donald C. Langevoort, Behavioral Theories of Judgment and Decision Making in Legal Scholarship: A Literature Review, 51 VAND. L. REV. 1499, 1503-06 (1998) (defining "anchoring" and other behavioral economic concepts that intersect with judicial decisionmaking); see also HOROwITZ, supra note 32, at 38-45 (noting how interest groups search out sympathetic plaintiffs).

47. David L. Faigman, "Normative Constitutional Fact-Finding”: Exploring the Empirical Component of Constitutional Interpretation, 139 U. PA. L. REV. 541, 578-80 (1991) (noting that social science data is rarely on point and, consequently, judges often manipulate such data).

48. Whether "members of the Supreme Court make decisions largely in terms of their personal attitudes about policy," it is demonstrably true that political party affiliation is an excellent predictor of judicial decisionmaking. LAWRENCE BAUM, THE SUPREME COURT 145 (7th ed. 2001). For empirical studies linking a Justice's ideology to the decisions that he or she reaches, see LEE EPSTEIN \& JACK KNIGHT, THE CHOICES Justice S MAKE $22-51$ (1998) (casting Justices as policy seekers who pursue a priori goals through judicial decisionmaking); Jeffrey A. Segal \& Harold J. Spaeth, The Supreme Court and the Attitudinal Model 226-31 (1993); Daniel R. Pinello, Linking Party to Judicial Ideology in American Courts: A Meta-analysis, 20 JUST. SYS. J. 219, 240-43 (1999); see also TUSHNET, supra note 39, at 155 (acknowledging that a judge's ideology often influences the public's perception of the judge's judicial decisionmaking); Cross, supra note 44, at 1543-44 (providing an overview of scholarly findings regarding the relationship between ideology and judicial decisionmaking); Frederick Schauer, Incentives, Reputation, and the Inglorious Determinants of Judicial Behavior, $68 \mathrm{U}$. CIN. L. REV. 615, 619-24 (2000) (examining sources of judicial decisionmaking). For a competing perspective, see Neil S. Siegel, Comment, Sen and the Hart of Jurisprudence: A Critique of 
even if political ideology is not explicitly at play, courts are susceptible to interest group capture. ${ }^{49}$

\section{B. Rethinking the Congressional Advantage}

Congress undoubtedly has the capacity to find social facts, while the courts face important obstacles in attempting to engage in accurate factfinding. ${ }^{50}$ Nevertheless, it is far from clear that Congress, in fact, will do a better job than the courts in this respect. Most critically, there is good reason to doubt whether Congress has the incentives to take factfinding seriously.

Public choice theory, for example, suggests that legislators are motivated solely by self-interest, not the public interest. In particular, legislators place their desire for reelection ahead of all else. ${ }^{51}$ Accordingly, legislation is a commodity that lawmakers provide interest groups in exchange for campaign contributions, endorsements, and promises of economic support for the districts they represent. Under this view, lawmakers could not care less about getting the facts right - what matters is delivering the goods. ${ }^{52}$

Whatever one's opinion of public choice theory, it is certainly true that lawmakers are partisans and that congressional decisionmaking, including factfinding, is often about the pursuit of desired outcomes. One simple measure of this phenomenon is the role that party control plays in committee agenda-setting and factfinding. When the Republicans captured the Senate in 1981, for example, social conservatives, by gaining control of the Judiciary Committee, ${ }^{53}$

the Economic Analysis of Judicial Behavior, 87 CAL. L. REV. 1581, 1597-1602 (1999) (discussing the failures of models of judicial behavior that do not adequately account for a judge's tendency to be bound by duty and the rule of law).

49. Jeremy Rabkin, Judicial Compulsions: How Public law Distorts Public POLICY 147-81 (1989) (revealing the capture of district and appeals courts in the District of Columbia by civil rights interests).

50. As Judge Richard Posner put it, the Justices also cannot escape "the unfortunate consequences of judicial ignorance of the social realities behind the issues with which they grapple." Posner, supra note 5, at 12.

51. Daniel A. Farber \& Philip P. Frickey, The Jurisprudence of Public Choice, 65 TEX. L. REV. 873, 891 (1987) (pointing out that a "legislator who is not reelected loses all the other possible benefits flowing from office").

52. In delivering the goods, of course, Congress may take factfinding into account. For example, there are occasions when a lawmaker who is sloppy with the facts may jeopardize her chance of being reelected, of successfully pursuing her ideology, or of maintaining status within her party.

53. Roger H. Davidson \& Walter J. Oleszek, Changing the Guard in the U.S. Senate, 9 LEGIS. STUD. Q. 635, 649 (1984) (describing Senator Strom Thurmond's efforts as the Chairman of the Senate Judiciary Committee to obtain a conservative majority on his panel). For an ar- 
were able to pursue their agenda with a vengeance, including the consideration of proposed human life legislation. Premised on a congressional finding that life begins at conception, this bill made its way through a Judiciary Committee subcommittee (including full-blown hearings and a subcommittee report) ${ }^{54}$ Were the Democrats in charge of the Judiciary Committee, it is inconceivable that this bill would have been taken up at all, let alone made its way through subcommittee. $^{55}$

The lesson here is that legislative choices, including factfinding, are driven by agenda-setters. ${ }^{56}$ In particular, committee chairs can pack their committees with like-minded thinkers, can determine when and what the committee investigates, and can arrange hearings in ways that frustrate the search for the truth. ${ }^{57}$ For example, committee staff may screen potential witnesses to ensure that they will say what

gument that the 1994 Republican takeover of Congress likewise resulted in value-driven, factinsensitive legislative oversight, see Robert Weissman, Oversight in the Republican Congress; Hearings Loss, AM. ProsPECT, Nov.-Dec. 1998, at 50, 50 (arguing that "the Republicans have abandoned any serious effort to use congressional oversight powers to ... launch meaningful investigations of serious social problems").

54. For a discussion of the politics of this legislation, see BARBARA HINKSON CRAIG \& DAVID M. O'BrIEN, ABORTION AND AMERICAN POLITICS 137-47 (1993).

55. Roger H. Davidson, The Lawmaking Congress, 56 LAW \& CONTEMP. Probs. 99, 107 (Autumn 1993) (noting that Democrats had earlier blocked numerous conservative initiatives, including abortion-related initiatives); see also id. at 108-09 (detailing the nexus between party affiliation and issues pursued by the Judiciary Committee). For this reason, Kenneth Shepsle has criticized the public choice model for focusing its energies on the desires of special interests. Kenneth A. Shepsle, Congress Is a "They," Not an "It": Legislative Intent as Oxymoron, 12 INT'L REV. L. \& ECON. 239, 240-48 (1992). Specifically, by giving all their emphasis and attention "to the agents who lobby for legislative products," Shepsle argues that public choice theorists undervalue the role that party affiliation and ideological predisposition play in legislative decisionmaking. Id. at 240.

56. C. LAWRENCE Evans, LeAdership in COMmitTeE: A COMPARATIVE ANALysis of LEADERSHIP BEHAVIOR IN THE U.S. SENATE 50-53 (1991) (highlighting the nexus between party control of committees and agenda-setting); William H. Riker \& Barry R. Weingast, Constitutional Regulation of Legislative Choice: The Political Consequences of Judicial Deference to Legislatures, 74 VA. L. REV. 373, 398, 400 (1988) (arguing that "an appropriately chosen agenda can lead anywhere an agenda-setter wants" and, consequently, the "Court's notion that majority outcomes result from a balancing of all relevant interests has little basis in theory or fact"). For an argument that this phenomenon is not at all inconsistent with lawmakers' honest pursuit of the public interest, see Farber \& Frickey, supra note 51, at 883-906 (analyzing methods for examining the relationship between interest groups, ideology, and legislative choice); Abner J. Mikva, Foreword to Symposium on Public Choice, 74 VA. L. REV. 167, 167 (1988) (arguing that good policy decisions emerge from partisan debate).

57. EvANS, supra note 56, at 107-10 (describing the powers of the committee chairman); see also Davidson, supra note 55, at 107 (describing how, in 1981, Strom Thurmond "recruited a conservative majority" for the Senate Judiciary Committee); Pilchen, supra note 10, at 367-68 (describing the power of the committee chairman to define the scope of a committee's investigation). At the same time, the ranking minority member and her staff chooses some of the witnesses who testify at hearings. 
the committee wants to hear. ${ }^{58}$ Assuming that committee members actually attend the hearing, the questioning format typically does not lend itself to "extended exchanges between members and witnesses, analysis of different points of view, or in-depth probing of one witness's views by another." 59

The quality of the legislative record may be compromised in yet another important way. When a factual record is assembled, "information from a variety of formal and informal sources-including lobbyists supporting or opposing legislation-can make its way into the record. " ${ }^{\circ 0}$ In part, lobbyists (as well as senior staffers) understand that courts sometimes look towards legislative history and, consequently, that it is useful to pad the legislative history in ways that support their objectives. ${ }^{61}$ Ultimately, with fundraising, constituent service, and other demands, members of Congress cannot pursue knowledge for knowledge's sake. Rather, most members simply follow the lead of agenda-setters within their party. ${ }^{62}$ And, while a conflict with either their interest group sponsors or voters may prompt a member to break ranks with party leaders, it is rarely the case that a member will risk party opprobrium simply because she views Congress's factfinding as substandard.

What then of Congress's power to modify its handiwork? Specifically, is Congress likely to find out if the factual premises of its en-

\footnotetext{
58. I speak from experience. On more than one occasion, I have been interviewed by committee staff-both to confirm that my writings reflect my current thinking as well as to help identify witnesses who will speak to a particular point. And while some hearings seek witnesses on both sides of an issue, it is also true that some hearings are stacked to better represent one side of an issue. E.g., CRAIG \& O'BRIEN, supra note 54, at 140 (detailing how Senator John East was forced to revamp hearings on proposed human life legislation in response to complaints of bias); Neal Devins, How Not to Challenge the Court, 39 WM. \& MARY L. REV. 645, 652-53 (1998) (highlighting the one-sided nature of Congress's Religious Freedom Restoration Act hearings).

59. Walter J. Oleszek, Congressional Procedures and the Policy Process 67 (1978).

60. Note, supra note 3, at 2322.

61. Note, Why Learned Hand Would Never Consult Legislative History Today, 105 HARV. L. REV. 1005, 1016 (1992) ("If no one knew that judges would consult legislative histories, these records almost certainly would look very different from the records produced today."). On the role of staffers in shaping the legislative agenda, compare John C. Yoo, Lawyers in Congress, 61 LAW \& CONTEMP. PROBS. 1, 16-18 (Spring 1998) (suggesting that staffers adhere to committee preferences), with Michael J. Glennon, Who's the Client? Legislative Lawyering Through the Rear-View Mirror, 61 LAW \& CONTEMP. PROBS. 21, $22-27$ (Spring 1998) (noting the ways in which staffers shape committee decisionmaking).

62. I do not mean to suggest here that members are disinterested either in ideology or serving the public interest. Rather, those types of battles typically play out in the selection of party leaders.
} 
actments are wrong and, if so, is Congress likely to correct factfinding mistakes? Perhaps, but probably not. To start, Congress is a reactive institution and, as such, it is doubtful that members keep track of legislation, even legislation they sponsor. ${ }^{63}$ Rather, when assessing the implementation of legislative programs, lawmakers make use of the "fire-alarm" approach, in which their attention is triggered by constituencies through "a system of rules, procedures, and informal practices that enable individual citizens and organized interest groups to examine... decisions... and to seek remedies from [Congress]." Consequently, absent interest group pressure, there is little chance that Congress will revisit the factual predicates of one of its enactments.

Even if interest groups do trigger a "fire alarm," interest group pressure and/or lawmaker interest must be sufficiently strong to overcome the burden of inertia. In particular, if party leaders think that "other measures have a stronger claim on the limited time and energy of the [legislative] body," Congress will leave (not so) well enough alone. ${ }^{65}$ Moreover, unless the measure harms those it was intended to benefit, the "fire alarm" is likely to fall on deaf ears. After all, the interest group triggering the alarm almost certainly opposed the measure's enactment. ${ }^{66}$ Finally, even if the agenda-setter is willing

63. Indeed, in 1993, the U.S. Court of Appeals for the D.C. Circuit and Congress agreed that the Clerk of the Court ought to inform Congress of instances where the D.C. Circuit construed a congressional statute. The reason for this reform: Congress was not paying attention to these decisions, some of which invalidated or severely constrained Congress's handiwork. Robert A. KATZMANN, COURTS AND CONGRESS 69-81 (1997) (describing current trends in statutory communication between the judicial and legislative branches); Abner J. Mikva, Why Judges Should Not Be Advicegivers: A Response to Professor Neal Katyal, 50 StAN. L. ReV. 1825, 1828 (1998) (noting that this experiment has "not caused any flurry of legislative action" perhaps because Congress is still not paying much attention).

64. Matthew D. McCubbins \& Thomas Schwartz, Congressional Oversight Overlooked: Policy Patrols Versus Fire Alarms, 28 AM. J. POL. SCI. 165, 166 (1984); see also William N. Eskridge, Jr., Overriding Supreme Court Statutory Interpretation Decisions, 101 YALE L.J. 331, 35966 (1991) (highlighting the critical role that interest groups play in prompting legislative responses to court decisions).

65. Lawrence C. Marshall, "Let Congress Do It": The Case for an Absolute Rule of Statutory Stare Decisis, 88 MicH. L. REV. 177, 190-91 (1989) (quoting H. Hart \& A. Sacks, The Legal Process: Basic Problems in the Making and Application of Law 1395 (1958) (unpublished manuscript)).

66. In other words, since "many abuses are often implemented on behalf of an agenda setter's constituents," it is unlikely that post-implementation factfinding will change the status quo ante. Shepsle, supra note 55, at 247. There is, however, one important exception to this rule of thumb: When party leadership in Congress changes, the relative power of interest groups also changes. As such, a change in party leadership may allow previously disenfranchised interest groups to trigger "fire alarms." 
to act, a significant minority within Congress or the President may well be able to block the legislation. ${ }^{67}$

Congress's reputation as a factfinding guru thus appears overstated. Indeed, notwithstanding the very real constraints that limit judicial factfinding, it may be that the courts do a better job of finding social facts than Congress. To start, while the "adjudicative process hears and considers less" than the legislative process, there may be a greater risk of bias in the legislative process. ${ }^{68}$ In particular, by allowing the opposing parties to "put into contention the major social science issues," ${ }^{69}$ the adversarial process sometimes yields a fairly complete presentation of the evidence. Correspondingly, although courts lack the staff and expertise to master social science evidence, they may well make as much use of this information as lawmakers and staffers pursuing a predetermined agenda. ${ }^{70}$ Furthermore, through the appointment of special masters and the utilization of injunctions to maintain control over a lawsuit, "policy-making judge[s]" obtain "information from as many groups as possible," including "experts in the

67. Marshall, supra note 65 , at 188 (noting that the principal power of agenda-setters is not "the affirmative power to pass legislation" but the negative power to block legislation that they oppose); see also Jerry L. MASHAW, Greed, ChaOs \& Governance: Using Public ChOice to Improve Public LAW 103 (1997) (employing game theory analysis of institutional positioning to explain the legislative response to judicial interpretation).

68. NeIL K. KOMESAR, IMPERFECT AlteRnAtives 141 (1994). In other words, as compared to the judicial process, the legislative process seems more partisan and more subject to interest group capture.

69. Michael A. Rebell \& Arthur R. Block, Educational Policy Making and THE COURTS 207 (1982) (concluding, from an empirical study of sixty-five federal trial court proceedings, that "the courts seem reasonably well equipped to undertake competent assessments of the conflicting social science data"); see also Pilchen, supra note 10, at 371-73 (discussing how pretrial discovery and cross-examination of experts facilitates judicial factfinding). On the other hand, if one of the parties fails to present "potentially significant countervailing arguments," the adversarial process breaks down. REBELL \& BLOCK, supra, at 207; see also HoROwITZ, supra note 32, at 48 (noting that "[t]he experts are usually partisans, employed by the parties, and their conclusions ... provide a skewed picture of the problem they purport to represent").

70. Indeed, there is some reason to think that courts are sufficiently skilled to make good use of this information. John Monahan \& Laurens Walker, Social Authority: Obtaining, Evaluating, and Establishing Social Science in Law, 134 U. PA. L. REV. 477, $495-517$ (1986) (suggesting that courts can work effectively with social science evidence but proposing some reforms that will improve court review of this evidence). Furthermore, by improving the training of lawyers and judges and by asking both parties and court-appointed amici to present additional evidence, judicial factfinding can be improved. Davis, supra note 27, at 1598-1603 (exploring judicial techniques for evaluating legislative facts); Arthur Selwyn Miller \& Jerome A. Barron, The Supreme Court, the Adversary System, and the Flow of Information to the Justices: A Preliminary Inquiry, 61 VA. L. REV. 1187, 1240-42 (1975) (proposing that the Supreme Court adopt a panel of social scientists to investigate matters of legislative fact). Of course, if Supreme Court Justices are simply putting their ideological preferences into effect, these reform proposals are of little use. See supra notes $46-48$ and accompanying text. 
field who [have] developed solutions through hands-on experience."71 Finally, just as stare decisis limits the Court's ability to reconsider factfinding mistakes, numerous disincentives stand in the way of Congress's reconsidering errant factfinding.

That the courts, on occasion, may do a better job factfinding than Congress is certainly suggestive but hardly conclusive evidence of how the Supreme Court should look at Congress when deciding whether to craft fact-dependent standards of review. In particular, the fact that Congress has the tools but may lack the incentives to take factfinding seriously does not necessarily mean that the Court should discount congressional factfinding. Rather, the foregoing comparative institutional analysis of judicial and legislative factfinding underscores how difficult and problematic it is for the Supreme Court to take factfinding into account when crafting standards of review. Nevertheless, real-world limits on congressional factfinding cast doubt on the presumption that Congress is an expert at finding facts and, as such, the Court-when sorting out whether to embrace fact-dependent standards of review-can count on Congress to take the relevant facts into account.

The question remains: Can the Court sort out when Congress has the institutional incentives to get the facts right? If so, the Court might be able to categorize when congressional factfinding is grounded in a hard look at the evidence and, alternatively, when it is simply a recording of interest group preferences. That enterprise is the subject of the next part of this Essay.

\section{CASE STUdies: TOWARdS AN INCENTIVE MODEL}

Parts I and II of this Essay have cast doubt on the related assumptions that the law-fact divide is fixed, mandated by the separation of powers, and sensible in light of Congress's comparative factfinding expertise. In sorting out how the Supreme Court can determine when Congress is likely to take factfinding seriously, this part will make use of case studies to look to the incentives that animate Congress. This case study approach offers several advantages over the generalist approach of the prior section. First, Supreme Court decisionmaking is itself built around doctrinal categories. Since the Justices' decision about crafting fact-sensitive standards of review will cut across a category of doctrine, there is significant risk in over-

71. FeEley \& Rubin, supra note 33, at 320. 
generalizing from either an overly broad data set (Congress's general interest in factfinding) or an overly narrow one (Congress's interest in factfinding when enacting a particular statute). Second (and more important), Congress's institutional incentives to get the facts right may be defined by subject area. For example, Congress may have different incentives on, say, separation of powers than it does on affirmative action. In this way, Justices who see the judicial role, first and foremost, as checking special-interest rent-seeking may well want to look to such case studies in sorting out whether to embrace fact-dependent standards or fact-insensitive rules. More to the point, as this part will show, Congress sometimes gives short shrift to factfinding and, with it, the public interest when legislation is the by-product of special-interest preferences.

In providing a preliminary assessment of these matters, this part will consider separation of powers, federalism, and affirmative action. Through these case studies this part seeks to discover both when Congress, in enacting legislation, does take a hard look at the facts and when Congress seeks to amend or repeal legislation because it comes to doubt the bill's factual premises. In identifying whether Congress has the institutional incentives to take factfinding seriously, moreover, this part will offer some suggestions about how an empirically minded Court would apply the resulting incentives model.

\section{A. Separation of Powers}

The 1996 Line Item Veto Act (struck down by the Court) 72 $^{72}$ and the Independent Counsel statute (upheld by the Court but killed by the Congress) $)^{73}$ call attention to the circumstances in which Congress, over time, is likely to get the facts right. In both cases, the institutional self-interest of Congress and the President resulted in strong incentives to keep these issues before Congress. Moreover, these incentives did not favor a particular political party or interest group. ${ }^{74}$ Finally, Congress was not seeking to expand its own power through

72. Clinton v. City of New York, 524 U.S. 417, 421 (1998).

73. Morrison v. Olson, 487 U.S. 654, 696-97 (1988). Congress allowed the statute to expire on June 30, 1999.

74. When Congress passed the Line Item Veto Act in April of 1996, for example, it was unclear exactly which party would enjoy the new power-that is, a Democratic or Republican President. In other words, Congress achieved agreement based on its inability to determine who the institutional beneficiaries of the Act would be. See also infra notes 90-95 and accompanying text (discussing party politics and the independent counsel). 
the enactment of either measure and, consequently, had little reason to stand behind these measures if they proved unworkable. ${ }^{75}$

The 1996 Line Item Veto Act was premised on the belief that omnibus appropriations had thrown off the balance of powers between Congress and the President. ${ }^{76}$ Nevertheless, by granting the President power to rescind discretionary appropriations, opponents of the measure warned that it would "take the appropriation process out of [Congress] ... and... transport it down to 1600 Pennsylvania Avenue." When enacting the measure, however, Congress did not know how the President would use the line-item veto. What it did know was that, after the 1994 Republican takeover of Congress, the then-prevailing anti-incumbency sentiment made it impossible for members to put their chances for reelection on the line by ignoring charges that Congress's fiscal irresponsibility jeopardized our nation's economic well-being. ${ }^{78}$ In other words, self-interest, not a detached look at the pertinent facts, helps explain why both Democrats and Republicans rallied behind the measure.

That self-interest figured prominently in the measure's approval, however, does not mean that Congress was poorly positioned to monitor presidential implementation of the statute and, if need be, correct its mistake. Most significantly, the Act was set to sunset in

75. Contrast, for example, the legislative veto struck down in INS v. Chadha, 462 U.S. 919, 959 (1983). Here, Congress may have seen the legislative veto as a low-cost way of micromanaging executive branch implementation of the law and in this way, aggrandizing its own power. For discussions of whether the legislative veto was used this way (or, alternatively, whether the legislative veto, more than anything, sought to cabin broad delegations of legislative power), see Harold H. Bruff, Legislative Formality, Administrative Rationality, 63 TEX. L. REV. 207, 213-23 (1984) (calling attention to how the legislative veto reduces the costs of legislative decisionmaking); Louis Fisher, The Legislative Veto: Invalidated, It Survives, 56 LAW \& CONTEMP. PROBS. 273, 275-92 (Autumn 1993) (detailing the history of the legislative veto and suggesting that both Congress and the White House benefited from legislative vetoes).

76. According to line-item veto proponents, Congress backed the President into a corner by waiting until the end of the fiscal year to enact one all-or-nothing omnibus appropriations (so that a presidential veto would shut the government down). Consequently, when enacting the Line Item Veto Act, Congress claimed that the line-item veto was a needed restoration of presidential power. John McCain stated: "Given Congress' predilection for unfunded and/or pork barrel spending, omnibus spending bills, and continuing resolutions, it would seem only prudent and constitutional to provide the President with functional veto power." 141 CONG. REC. S101 (daily ed. Jan. 4, 1995) (statement of Sen. McCain).

77. 141 CONG. REC. H1090 (daily ed. Feb. 2, 1995) (statement of Rep. Kanjorski). For a recounting of proponents' and opponents' arguments, see generally Neal E. Devins, In Search of the Lost Chord: Reflections on the 1996 Item Veto Act, 47 CASE W. RES. L. REV. 1605 (1997).

78. In particular, with the failure of Gramm-Rudman and post-1990 budget summits to check the national debt, Congress needed either to rely on politically costly mechanisms (increase taxes, reduce spending) or find a new structural gimmick/approach. 
$2005^{79}$ and, consequently, the Act's durability was tied to its continuing appeal to Congress. Furthermore, the Act was sure to trigger numerous "fire alarms," for any time a special interest saw its favored project rescinded, that interest would almost certainly complain to its allies in Congress. ${ }^{80}$ The individual interests of members of Congress and Congress's institutional interest in preserving its budget priorities were therefore likely to coalesce if the President made aggressive use of the line-item veto. ${ }^{81}$

By striking down President Clinton's first exercise of the lineitem veto, Congress's claim that the line-item veto would restore, not disrupt, the balance of powers was never put to the test. ${ }^{82}$ In light of the above-identified incentives for Congress to monitor the President's use of the line-item veto, an empirically minded Court might have deferred a definitive ruling, allowing the line-item veto experiment to continue by making use of a flexible fact-dependent standard of review.

In Clinton v. City of New York, ${ }^{83}$ however, the Justices divided six to three on the question of whether the line-item veto violated the constitutional command that the President veto (all, not part of) a bill before (not after) it becomes law. By mooring its decision to a debatable interpretation of the constitutional text, ${ }^{84}$ the Court gave short shrift to those institutional incentives that might well have guided an

79. Line Item Veto Act, Pub. L. 104-130, § 5, 110 Stat. 1200, 1212 (1996).

80. For this very reason, after the first few exercises of the line-item veto, legislators began having second thoughts about their original support for the law. Lisa Hoffman Scrips, Clinton Wields Line-Item Veto Lightly: Congress Piles Up 750 Pet Projects on Military Spending Bill; President Kills Just 13 of Them, DenVER Rocky MTN. News, Oct. 15, 1997, at 32A.

81. Indeed, Congress had ways to insulate preferred constituents from the line-item veto. For example, by identifying program priorities in unofficial and informal documents, Congress could communicate its preferences to agencies without subjecting its handiwork to presidential cancellations. Devins, supra note 77, at 1624. More significantly, the President had little incentive to make use of his line-item veto power. In particular, since any rescinded appropriation would go into a lockbox for budget deficits, Presidents could not shift funds (and thereby reward political allies or constituent interests). For further discussion, see Terry M. Moe \& William G. Howell, The Presidential Power of Unilateral Action, 15 J.L. ECON. \& ORG. 132, 143-48 (1999) (detailing how the individual interests of members of Congress often diverge from Congress's institutional interests).

82. In this way, the "facts" at issue in the line-item veto case were not truly knowable at the time of the decision. In other words, unlike cases where Congress's factfinding is based on a judgment of the here and now, the line-item veto case-for an empirically minded Court-was very much about the likelihood that Congress would revisit its handiwork over time.

83. 524 U.S. 417 (1998).

84. For critiques of the Court's reasoning, see generally Elizabeth Garrett, Accountability and Restraint: The Federal Budget Process and the Line Item Veto Act, 20 CARDOzO L. REV. 871 (1999), and H. Jefferson Powell \& Jed Rubenfeld, Laying It on the Line: A Dialogue on Line Item Vetoes and Separation of Powers, 47 DUKE L.J. 1171 (1998). 
empirically minded Court. The Court's 1988 decision in Morrison v. Olson, ${ }^{85}$ upholding the Independent Counsel statute, is cut from an entirely different cloth. There, the Court did employ a fact-dependent standard of review. ${ }^{86}$ In so doing, the Court embraced a standard of review consistent with the incentives model. ${ }^{87}$

The story of the Independent Counsel statute is, of course, tied to Richard Nixon's decision to fire Archibald Cox in the midst of the Watergate scandal. In 1974 and again in 1976, voters retaliated against Nixon loyalists, signaling that "support for post-Watergate reform was an electorally significant position to take." ${ }^{, 8}$ Congress did just that, creating a court-appointed Independent Counsel who, absent "extraordinary impropriety," could not be removed by the Attorney General.

When enacting the statute, Congress could not anticipate how Independent Counsel investigations would affect Justice Department control of criminal investigations. Through a five-year sunset provision, ${ }^{90}$ however, Congress preserved its ability to bargain over the terms of the statute (including the elimination of the Special Prosecutor) with future presidents. For example, responding to Reagan administration complaints, Congress, in 1983, increased the Attorney General's discretion in requesting a court-appointed Independent Counsel, ${ }^{91}$ lowered the standard for removal to "good cause,", and urged the Independent Counsel to follow Justice Department guidelines "except where not possible." 93

85. 487 U.S. 654 (1988)

86. See id. at 679 (describing the Independent Counsel as "a temporary 'office' the nature and duties of which will by necessity vary with the factual circumstances giving rise to the need for an appointment in the first place").

87. I do not mean to suggest, however, that the Court in Morrison explicitly took this incentives model into account. The Justices, for example, may have been reluctant to overturn a statute designed to check post-Watergate executive branch abuses. For further discussion, see infra notes 181-82 and accompanying text (criticizing the Court's application of this factdependent standard of review).

88. Katy J. Harriger, IndePendent Justice: The Federal SPeCial Prosecutor in AMERICAN POLITICS 51 (1992).

89. Pub. L. 95-521, § 601, 92 Stat. 1824, 1872 (1978) (codified as amended at 28 U.S.C. $\S 596)$ (1994 \& Supp. 2000).

90. 28 U.S.C. $\$ 599(1994)$.

91. 28 U.S.C. $\$ 592(\mathrm{a})(2)(\mathrm{A})-(\mathrm{B})(1994)$.

92. 28 U.S.C. $\$ 596(\mathrm{a})(1)(1994)$.

93. 28 U.S.C. $§ 594(f)$ (1994). In 1987, however, Congress responded to alleged abuses by Attorney General Edwin Meese by limiting Attorney General discretion. HARRIGER, supra note 88, at 77-89. In 1999, legislation was introduced to reform the Independent Counsel statute by, among other things, narrowing the jurisdiction of Independent Counsel investigations. H.R. 117, 106th Cong. (1999). 
The Supreme Court was no doubt aware of this give-and-take process when deciding the constitutional fate of the Independent Counsel statute. What the Justices could not anticipate was Lawrence Walsh's six-year investigation of Iran-Contra or Kenneth Starr's investigation of President Clinton, but these two investigations and, with them, the apparent death of the Independent Counsel statute point to the correctness of the result reached in Morrison. ${ }^{94}$ Like the Line Item Veto Act, there was every reason to think that bargaining between the branches would, over time, result in an equilibrium of sorts-in this case, an Independent Counsel statute that did not undermine Attorney General control or, alternatively, no Independent Counsel statute at all. More to the point, presidents (and their allies in Congress) were well-positioned to defend Department of Justice interests. The Act's sunset provision, for example, allowed the President to bargain with Congress over the statute (and, if need be, veto the reauthorization). Furthermore, because Democratic and Republican administrations would each be the target of Independent Counsel investigations, the possibility that the statute would harm the political fortunes of one but not the other party seemed doubtful. ${ }^{95}$ Consequently, it is hardly surprising that, at the end of the day, the Justice Department and Congress both agreed that the factual premises underlying the statute were incorrect and that, for the time being at least, it was better to have no statute than a fatally flawed one. ${ }^{96}$

The President and Congress, as the above discussion suggests, have little choice but to react to and make accommodations with each other. As a result, Congress seems especially likely to revisit its separation of powers handiwork. ${ }^{97}$ In so doing, moreover, the President

94. It is important to keep in mind that, when reviewing Morrison, the D.C. Circuit had overturned the Independent Counsel statute. In re Sealed Case, 838 F.2d 476, $517-18$ (D.C. Cir. 1988). For this reason, the Supreme Court could not use its agenda control power to delay a decision. For further discussion, see infra notes 181-82 and accompanying text.

95. Much the same can be said of the line-item veto. Democratic presidents would disappoint Republicans by protecting Democratic-sponsored initiatives, and vice versa.

96. See The Future of the Independent Counsel Act: Hearing Before the Senate Comm. on Governmental Affairs, 106th Cong. 243, 251 (1999) (statement of Attorney General Janet Reno) (arguing that the Independent Counsel statute subverts Justice Department enforcement of the criminal laws).

97. There are exceptions to this rule of thumb. Impeachment, for example, is an occasion where members of Congress will not bargain with each other and the President over an extended period of time. For this reason, the built-in incentives of a repeat-player system are less likely to be a factor. Perhaps for this reason, House Republicans gave short shift to factfinding during the Clinton impeachment. In particular, relying on Special Counsel Starr's report, the House voted to send articles of impeachment to the Senate. The only independent factfinding initiated by Republican leadership took place during the Senate trial (at a time when the im- 
may well have an opportunity to bargain with Congress over the terms of power-sharing arrangements. For an empirically minded Court, there is little reason to cut off this ongoing give-and-take process by issuing rigid rules-based decisions. In particular, when Congress and the President have both the incentives and the opportunity to defend their institutional self-interest, it may well be that bargaining between the branches will take into account the lessons of past experience. Put another way: Why should an empirically minded Court eschew facts (by imposing a fact-insensitive rule) when there is ample reason to think that, over time, Congress and the President will take the facts into account by moderating their handiwork. This, after all, is what happened with the Independent Counsel statute and there is ample reason to think that-had the Court not intervened-the branches would have made accommodations to each other in implementing the Line Item Veto Act. Consequently, in approaching separation of powers issues, an empirically minded Court ought either to employ fact-dependent standards of review and/or delay a definitive decision by making use of certiorari denials and other forms of agenda control. ${ }^{98}$ In this way, Congress and the President are given breathing room to bargain with each other. ${ }^{99}$

peachment effort appeared doomed).

98. In some ways, INS v. Chadha, 462 U.S. 919 (1983), follows this model. Assuming that the Justices-based on decades of experience - thought that Congress was using the legislative veto to micromanage executive branch implementation of the law, a decision striking down the legislative veto, of course, makes sense. Moreover, by concluding that the legislative veto is inconsistent with the Constitution's text (a purely legal decision), the Court both made it difficult for Congress to challenge its reasoning and preserved its option of making use of fact-dependent standards in future cases. On the other hand, if the legislative veto was, more than anything, a defensive measure that Congress utilized to protect its turf when delegating power to the executive, the Chadha decision inappropriately limited Congress from bargaining with the White House over power-sharing arrangements. See supra note 75 and accompanying text (describing different conceptualizations of the legislative veto).

99. More to the point, since Congress may well have the institutional incentives to take a hard look at the facts underlying its enactments, there is little reason for an empirically minded Court to make use of a rigid rule that cuts off a power-sharing arrangement before it is put into effect. Specifically, since neither Congress nor the Court knows precisely how an untested power-sharing arrangement will work, the Court has ample reason to give Congress the benefit of the doubt in separation of powers cases. To do otherwise, an empirically minded Court, in effect, would declare that Congress-contrary to what this case study suggests-cannot be trusted in this area. For further discussion, see infra note 182 and accompanying text (explaining how the Court may make use of "procedural minimalism" to facilitate ongoing bargaining between the branches). 


\section{B. Federalism}

Unlike the separation of powers issues, federalism concerns do not provide incentives for Congress and the President, following judicial approval of a statute, to bargain over its terms and, in so doing, revisit its factual premises. Rather, the incentives of Congress and its constituents are to expand the scope of federal power, not contract that power in response to a "fire alarm" trigger. Consider, for example, the minimal role played by United States v. Lopez ${ }^{100}$ in shaping Congress's views on federalism. By striking down legislation prohibiting firearm possession at or near a school, ${ }^{101}$ the Court signaled to Congress that federalism concerns might play a significant role in Court review of national legislation. Congress has not taken this message to heart, however. The case is hardly referred to in legislative deliberations $^{102}$ and, more importantly, the Republican Congress (ostensibly committed to states' rights) has increasingly federalized all types of subjects. ${ }^{103}$

Congress's expansionist tendencies are easily understood. ${ }^{104}$ First, constituent interests increasingly see national legislation as preferable to state and local measures. It is harder for regulated parties to avoid national legislation and, as compared to lobbying fifty state legislatures, there are fewer transaction costs associated with national legis-

100. 514 U.S. 549 (1995)

101. Id. at 567-68.

102. From 1995 to 2000, Lopez was mentioned forty-nine times in the Congressional Record. Twenty-seven of those references occurred in 1995 and 1996, a time when Congress responded to Lopez by enacting a modified guns-in-the-schools ban-one requiring the federal government to prove that the firearm either moved in interstate commerce or otherwise affected interstate commerce. Louis Fisher \& NeAl DeVins, Political Dynamics of Constitutional LAW 90 (3d ed. 2000).

103. William Marshall, American Political Culture and the Failures of Process Federalism, 22 HARV. J.L. \& PUB. POL'Y 139, 141-44 (1998); Edwin Meese III, Big Brother on the Beat: The Expanding Federalization of Crime, 1 TEX. REV. L. \& POL. 1, 4 (1997).

104. For excellent treatments of this subject, see Barry Friedman, Valuing Federalism, 82 MINN. L. REV. 317, 365-78 (1997) (describing the "centripetal forces" that account for the tendency toward centralization of regulatory authority); Marshall, supra note 103, at 1440 ("[W]hether a matter will be federalized depends entirely upon its attractiveness, as a substantive political issue, to federal officeholders. At best, the federalism argument will enter the debate only as a secondary rhetorical point."). For (I think incorrect) arguments that Congress is attentive to the scope of its power vis-à-vis the states, see JESSE H. CHOPER, JUDICIAL REVIEW AND the NATIONAl Political Process 175-80 (1980); Larry Kramer, Understanding Federalism, 47 VAND. L. REV. 1485 (1994); Herbert Wechsler, The Political Safeguards of Federalism: The Role of the States in the Composition and Selection of the National Government, 54 CoLuM. L. Rev. 543 (1954). For a critique of those arguments, see William P. Marshall, Federalization: A Critical Overview, 44 DePaul L. Rev. 719, 725-36 (1995). 
lation. ${ }^{105}$ Second, thanks both to changes in media coverage and modern political advertising, the political culture has become increasingly nationalized. ${ }^{106}$ Third (and relatedly), voters expect lawmakers to support politically popular legislation, not block it for a principle as abstract as Congress's failure to show-through factfinding - that the measure addresses a national problem. ${ }^{107}$ "A lawmaker who voted against the national Megan's Law or the national car-jacking law, for example, would almost certainly be characterized as being soft on crime in her opponent's next thirty-second sound bite."

Two examples, the Gun-Free School Zones Act ${ }^{109}$ (GFSZA) and the Religious Freedom Restoration Act $^{110}$ (RFRA), will illustrate why Congress cannot be counted on to take factfinding seriously on federalism questions. When enacting the GFSZA, Congress did not find that gun possession affected interstate commerce, nor did any member of Congress (or, for that matter, any witness at a House hearing on the bill) suggest that interstate commerce was at issue. ${ }^{111}$ And why should they? The tragedy of guns in schools was very real and politically popular. ${ }^{112}$ Also, when enacting the bill, the Supreme Court's

105. Friedman, supra note 104, at 373-76; Jonathan R. Macey, Federal Deference to Local Regulators and the Economic Theory of Regulation: Toward a Public-Choice Explanation of Federalism, 76 VA. L. REV. 265, 271-73 (1990). Also, a lobbyist who focuses her efforts on Washington, D.C., travels less, hangs out with national power brokers, eats at better restaurants, etc.

106. Marshall, supra note 103, at 151-53.

107. By analogy, states and local interests will only resist Congress's expansionist tendencies when something they value is on the line. Elizabeth Garrett, Enhancing the Political Safeguards of Federalism? The Unfunded Mandates Reform Act of 1995, 45 U. KAN. L. REV. 1113, 1128-31 (1996) (explaining why powerful interest groups, like the National League of Cities and the National Association of Governors, who are ostensibly committed to "states' rights" may fail to guard the interests of federalism). When it comes to the federalization of crime, for example, state governments have little interest in speaking up on behalf of criminal defendants. In contrast, state and local interests successfully fought off Clinton-era initiatives to expand the scope of federal regulations over traditional boundaries of state and local authority. FISHER \& DEVINS, supra note 102, at 91-92.

108. Id. at 145 .

109. The GFSZA was discussed and repudiated in United States v. Lopez, 514 U.S. 549 (1995).

110. The RFRA was discussed and repudiated in City of Boerne v. Flores, 521 U.S. 507 (1997).

111. Barry Friedman, Legislative Findings and Judicial Signals: A Positive Political Reading of United States v. Lopez, 46 CASE W. RES. L. REV. 757, 765-66 (1996). The issue was raised indirectly, for one witness called attention to Congress's failure to specify its constitutional authority to enact the legislation. $I d$. at 766 .

112. Congressional hearings and debates focused on tragic examples of gun violence in schools. While the National Rifle Association submitted testimony opposing the legislation as "a symbolic gesture," "com[ing] only two months from the general elections," Congress paid 
Commerce Clause jurisprudence did not require findings of fact and was otherwise extremely deferential. With no powerful constituent interest resisting the measure, there was much to lose and nothing to gain by opposing this measure in order to sort out the facts. ${ }^{113}$ Ironically, after the Supreme Court decided to review a constitutional challenge to the statute, Congress-recognizing that its handiwork was on the line-quickly added an amendment to the bill, finding (without hearings) that gun possession affected interstate commerce. ${ }^{114}$

The RFRA, an exercise of Congress's Fourteenth Amendment, Section 5 enforcement powers, is an even more egregious example of Congress's willingness to trade off factfinding. To place the statute within the ambit of Court precedent, Congress was advised to make specific findings of fact "that formally neutral, generally applicable laws have historically been instruments of religious persecution, that enacting separate religious exemptions in every statute is not a workable means of protecting religious liberty, and that litigation about governmental motives is not a workable means of protecting religious liberty." ${ }^{115}$ Instead, Congress's consideration of the RFRA focused exclusively on protesting the wrongness of Employment Division, Department of Human Resources of Oregon v. Smith, ${ }^{116}$ a 1990 Supreme Court interpretation of the Free Exercise Clause. Congressional hearings showcased witnesses from religious and other interest

scant attention to claims that the GFSZA did little more than duplicate existing state statutes. See Gun-Free School Zones Act of 1990: Hearing Before the Subcomm. on Crime of the House Comm. on the Judiciary, 101st Cong. 79 (1990) (statement of James Jay Baker, Director, NRA).

113. Anti-carjacking legislation is another example of Congress's willingness to trade off factfinding in order to do what is politically popular. When enacting the Anti Car Theft Act of 1992, Pub. L. No. 102-519, 106 Stat. 3384 (codified at 18 U.S.C. § 2119 (1994)), Congress specifically found that car thefts were on the rise and, consequently, legislation was necessary to protect both "human life and ... the economic well-being of the Nation." Id. At that time, "the media ha[d] seized upon joyriding and ... [u]sing the common links of cars and stereotypes, the media ha[d] created the impression of an epidemic of out-of-control young Black men engaging in auto theft." Dwight L. Grene, Naughty by Nature: Black Male Joyriding-Is Everything Gonna Be Alright?, 4 COLUM. J. GENDER \& L. 73, 75 (1994). What the media did not report was that car theft, in fact, was on the decline. $I d$. at 76 n.10. Notwithstanding this false premise, interest groups, both when the legislation was enacted and in subsequent years, never triggered a "fire alarm," and, consequently, Congress never reconsidered its findings. For further discussion, see Rogovin, supra note 38, at 1772-78.

114. 18 U.S.C. $\$ 922(q)$ (1994).

115. Religious Freedom Restoration Act of 1991: Hearings on H.R. 2797 Before the Subcomm. on Civil and Constitutional Rights of the House Comm. on the Judiciary, 102d Cong. 331 (1992) (statement of Professor Douglas Laycock).

116. 494 U.S. 872 (1990). 
groups, nearly all of whom attacked Smith. ${ }^{117}$ Lawmakers read from a nearly identical script, routinely condemning Smith and calling upon the Justices to reverse it. ${ }^{118}$ In the end, with virtually no interest group opposition to the measure, Congress gave short shrift to factfinding in order to do precisely what RFRA's interest group sponsors asked for, that is, repudiate Smith.

The lesson of the GFSZA and the RFRA is simple. Congress finds facts when there is a reason to do so. If the Court, for example, were to precondition approval of legislation on formalized factfinding, Congress almost certainly would comply. Such factfinding might well be boilerplate, however, for interest groups and congressional sponsors would see formalized findings as essential to the enterprise. ${ }^{119}$ On occasion, however, the convergence of interest group and party leader preferences demand that Congress take factfinding seriously. The 1964 Civil Rights Act is an example of this phenomenon. Here, there was formidable resistance to grounding the Act's public accommodation provision in the Commerce Clause; while Southern lawmakers opposed the Act altogether, some Republican Party leaders wanted to ground the Act in the Fourteenth Amendment. ${ }^{120}$ In response, Act sponsors in Congress, as well as Kennedy administration officials, worked overtime-sometimes by arguing the facts, sometimes by amassing a broad array of interest group supporters of the Act - in convincing lawmakers that the statute did implicate interstate commerce. $^{121}$

While Congress certainly did a yeoman's job of documenting the nexus between private discrimination and interstate commerce, ${ }^{122}$ there is a certain irony in heralding the 1964 Act as a model of legislative factfinding. Act sponsors sought to manipulate the process in ways that point to the value-laden nature of legislative factfinding. In

117. For a review of the RFRA's legislative history, see Devins, supra note 58, at 651-56.

118. Lawmakers also applauded the unprecedented coalition of interest groups that came together in support of the RFRA. Id. at 652-53.

119. Harold J. Krent, Turning Congress into an Agency: The Propriety of Requiring Legislative Findings, 46 CASE W. RES. L. REV. 731, 735-36 (1996) (arguing that the main effect of Lopez will be the loading of statutes with boilerplate findings); H. Jefferson Powell, Enumerated Means and Unlimited Ends, 94 MiCH. L. REV. 651, 651-52 (1995) (same).

120. Hugh Davis Graham, The Civil Rights ERA 87-95 (1990).

121. Id. at $90-94$.

122. The Senate Commerce Committee held twenty-three separate sessions on the measure; a subcommittee of the House Judiciary Committee spent twenty-two days in hearings and another seventeen in executive session on the measure. Mark E. Herrmann, Note, Looking Down from the Hill: Factors Determining the Success of Congressional Efforts to Reverse Supreme Court Interpretations of the Constitution, 33 WM. \& MARY L. REV. 543, 571-72 (1992). 
particular, with southerner James Eastland chairing the Senate Judiciary Committee, an arrangement was worked out whereby the Senate Commerce Committee ("loaded [with members] in favor" of public accommodations) would have jurisdiction over this part of the Act. ${ }^{123}$ In this way, the story of the 1964 Civil Rights Act is mixed. On the one hand, Congress made use of its ample resources to find facts and, given opposition to the bill, did so in a highly credible way. On the other hand, by choreographing this effort to reach a particular conclusion, the 1964 Civil Rights Act also points to the dangers of looking to Congress to limit the scope of its federalism-implicated powers by taking factfinding seriously.

Finally, on federalism matters, there is little incentive for Congress to reconsider its handiwork. On issues as diverse as guns in schools, religious liberty protections, and civil rights, it is doubtful (once the coalition supporting the bill is sufficiently strong to push it through Congress) that an interest group will be able to trigger a "fire alarm" calling the bill into question. Even if an alarm is triggered, it might well take a sea change in attitudes to form a coalition sufficiently strong to convince both lawmakers and the President to disrupt the expectation interests of the coalition supporting the original bill. $^{124}$

How then should an empirically minded Court approach federalism-related issues? To start with, there is a great cost in embracing fact-dependent standards. In particular, after holding (in 1937) that Congress's power to regulate commerce extends to anything and everything "affecting commerce," ${ }^{125}$ the Court encouraged Congress to make findings that commerce indeed was affected, findings that the Court could not challenge (or at least could not challenge without ap-

123. GRAHAM, supra note 120 , at $93-94$.

124. Once a measure is approved, an "endowment effect" is created whereby beneficiaries feel a sense of entitlement so strong that the costs of changing the status quo are especially high. Langevoort, supra note 46, at 1517 ("[H]aving an existing property interest creates a greater attachment ... than would be expressed by others not in possession ...."). Furthermore, on federalism matters, Congress has little incentive to police itself in ways that constrain its power. Consider, for example, unfunded mandates reform, one of the centerpieces of the Contract with America. Legislation was enacted, Unfunded Mandates Reform Act of 1995, Pub. L. No. 104-4, 109 Stat. 48, but it did not end unfunded mandates. Many of the mandates concerning civil rights, the disabled, and other categories are specifically exempted. Id. For the mandates that are covered, the statute merely requires the Congressional Budget Office to flag any bill that creates an unfunded mandate of $\$ 50$ million or higher on the states. Id. But see WILLIAM N. ESKRIDGE, JR. ET AL., LEGISLATION AND STATUTORY INTERPRETATION 180 (2000) (noting that the Act is more than symbolic politics, for any member of Congress can force consideration of unfunded mandates and, in this way, compel lawmakers to deliberate over federalism values).

125. NLRB v. Jones \& Laughlin Steel Corp., 301 U.S. 1, 6-7 (1937). 
pearing to act as a super-legislature). ${ }^{126}$ For this very reason, Justice Robert Jackson, after authoring Wickard v. Filburn, ${ }^{127}$ lamented, "I really know of no place where we can bound the doctrine." ${ }^{128}$ An empirically minded Court, given Congress's expansionist tendencies, would never have embraced this open-ended, fact-dependent "affecting commerce" standard. Given that interest groups grow in power and number over time ${ }^{129}$ an empirically minded Court would have feared that a fact-dependent standard would accomplish little more than the advantaging of special interests at the expense of the public interest. At the same time, once the New Deal Court let the "affecting commerce" genie out of the bottle, ${ }^{130}$ an empirically minded Court might well make use of boundary control standards that would deem some federalism-related issues to be questions of law, not fact. ${ }^{131}$

126. For a somewhat competing perspective, see Frickey, supra note 21, at 711-12. For Frickey, judicial acceptance of an integrated national economy did not come with Jones \& Laughlin in 1937; instead, Jones \& Laughlin speaks to Congress's "sustained and increasingly thoughtful" showing that there was, in fact, an integrated national economy. Id. Under this view, the Court exercised some caution before Wickard, a case where the Court's embrace of a pro-Congress standard was unquestionable. At the same time, by placing great emphasis on congressional factfinding in Jones \& Laughlin, the Justices, undoubtedly, placed the ball in Congress's court, for once Congress found facts, it would be very difficult for the Court to meaningfully check Congress.

127. 317 U.S. 111 (1942) (upholding the power of the government to count a farmer's private consumption of wheat as part of a government-prescribed quota).

128. Barry Cushman, Formalism and Realism in Commerce Clause Jurisprudence, 67 U. CHI. L. REv. 1089, 1145 (2000) (quoting a letter Justice Jackson sent to his friend (and later Associate Justice) Sherman Minton).

129. MANCUR Olson, The Rise AND DECLINE OF NATIONS 40 (1982) (charting the growth of interest groups).

130. It may be, of course, that a desire to uphold post-New Deal exercises of the commerce power may have made the "affecting commerce" standard irresistible. See generally WILLIAM E. Leuchtenburg, The Supreme Court Reborn (1995) (arguing that the Court's expansive approach to the Commerce Clause was a by-product of political pressures, including FDR's Court-packing plan). For a competing perspective, see generally Barry Cushman, Rethinking the New Deal Court, 80 VA. L. REV. 201 (1994).

131. This is precisely what happened in both the Gun-Free School Zones and Violence Against Women Act cases. Declaring that Congress's Commerce Clause authority is limited to "the instrumentalities, channels, or goods involved in interstate commerce," the Court concluded that congressional factfinding was irrelevant. United States v. Morrison, 529 U.S. 598, 617 (2000) (rejecting the argument "that Congress may regulate noneconomic, violent criminal conduct" and, in so doing, deeming irrelevant legislative factfinding pointing to "that conduct's aggregate effect on interstate commerce"); United States v. Lopez, 514 U.S. 549, 551, 560, 567 (1995) (suggesting that-no matter what findings Congress may make-gun possession is not "economic activity" and, as such, cannot "substantially affect any sort of interstate commerce"). For this reason, I think that Bryant and Simeone are wrong to suggest that Lopez and Morrison are inconsistent with the traditionalist law-fact divide. Bryant \& Simeone, supra note 4, at 33944. With that said, I do not mean to suggest that the Court followed the incentives model that I am laying out in this Essay. But a Court following this model, given the constraints of precedent, 
What then of the RFRA? Here, Congress was acting on its Section 5 enforcement powers, but, as when it legislates pursuant to its Commerce Clause powers, there is reason to think that specialinterest politics, not factfinding in the public interest, dominated congressional decisionmaking. For this reason, an empirically minded Court might well embrace standards, such as the one utilized in City of Boerne v. Flores ${ }^{132}$ that allow the Justices to toss aside legislative action taken under the enforcement powers of the Fourteenth Amendment, perceived to be about rights (law), rather than remedies (facts). ${ }^{133}$

\section{Affirmative Action}

Affirmative action legislation, like legislation that expands Congress's federalism-implicated powers, reinforces the secondary role that factfinding plays in legislative deliberations. Here, the power of committees, the intensity of preferences among constituents and, correspondingly, the members who represent them, and Congress's reactive nature are on full display. As when they legislate on federalismrelated issues, moreover, there are few incentives for members of Congress to reconsider preexisting affirmative action programs. Congress's longstanding approval of both set-asides for minority business enterprises and diversity preferences for minority broadcasters illustrate these points. ${ }^{134}$

Set-aside provisions of the Public Works Employment Act of $1977^{135}$ and the Surface Transportation Assistance Act of $1982^{136}$ highlight the pivotal role that interest group preferences, not factfinding, play in affirmative action legislation. Congress, in enacting these

might well have chosen the same course.

132. 521 U.S. 507 (1997).

133. Recent Supreme Court decisions on the Americans with Disabilities Act, as well as age discrimination and patients rights legislation, support this conclusion. See supra note 19. By allowing the Justices to review congressional factfinding in sorting out whether the matter before them is one of law or facts, the City of Boerne standard maximizes judicial discretion. See supra note 18 and accompanying text; infra note 162 and accompanying text.

134. I do not mean to suggest that I oppose affirmative action or that a factual basis does not exist for these programs. See Neal Devins, Metro Broadcasting, Inc. v. FCC: Requiem for a Heavyweight, 69 TEX. L. REV. 125, 150-55 (1990) (defending the constitutionality of remedial preferences).

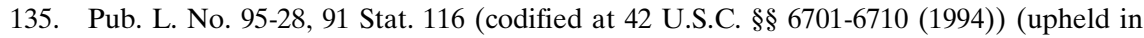
Fullilove v. Klutznick, 448 U.S. 448 (1980)).

136. The provision first appeared in 1983, Pub. L. No. 97-424, 96 Stat. 2097 (1983) (codified at 23 U.S.C. $\S 101$ (1994), 49 U.S.C. $\$ 1602$ (1994)), and has been reenacted several times, most recently in 1998. 
measures, made no formal findings of fact, nor did it hold hearings. ${ }^{137}$ Instead, by way of floor amendments added to larger public works bills, Congress, with virtually no debate, approved these set-aside programs. ${ }^{138}$ The simple explanation for this expedited consideration is logrolling; in particular, members of the Congressional Black Caucus, quite rightly, wanted to "get a fair share of the action" from these public works measures. ${ }^{139}$

In Fullilove v. Klutznick, ${ }^{140}$ however, the Supreme Court embraced traditionalist notions of Congress's superior factfinding skills when upholding the 1977 Public Works Act set-aside. Deeming the Act "a considered decision of the Congress" ploying the analytical rigor of rational basis review, ${ }^{142}$ Fullilove is a paean to Congress. ${ }^{143}$ An empirically minded Court would have steered clear of such deferential fact-dependent decisionmaking; rather, fearful that such a standard might limit its power to check race-based special-interest politics, empirically minded Justices, at a minimum, would have wanted to defer judgment on what standard to employ in affirmative action cases until they knew more about the politics underlying these measures. ${ }^{144}$

Diversity preferences in broadcasting, upheld by the Supreme Court in Metro Broadcasting, Inc. v. FCC, ${ }^{145}$ are another example to

137. For an accounting of the legislative history, see Drew S. Days, III, Fullilove, 96 YALE L.J. 453, 465-66, 471-73 (1987).

138. Consider, for example, the Public Works Act set-aside. The House and Senate each approved the provision the same day that it was proposed. 123 CONG. REC. H5332 (1977); id. at S7156.

139. 123 ConG. ReC. 5327 (1977) (statement of Rep. Mitchell). And while many in Congress may have seen these measures as necessary to remedy discrimination, Congress's decisionmaking processes suggest otherwise. Days, supra note 137, at 465-66 (noting that, unlike most civil rights laws, "the minority set-aside provision was enacted into law without hearings or committee reports, and with only token opposition").

140. 448 U.S. 448 (1980).

141. Id. at 473 .

142. Id. at 485 (noting "the well-established concept that a legislature may take one step at a time to remedy only part of a broader problem").

143. Indeed, since it could not say much about the legislative history of the 1977 set-aside, the decision is replete with references to congressional and agency factfinding of an affirmative action program that was not before the Court. Id. at 463-72; see also Days, supra note 137, at 463-77 (criticizing this practice).

144. For example, because Congress may take into account both earlier factfinding and information learned outside of the legislative process, it would be wrong for the Court to assume the worst about Congress simply because a measure was enacted without much debate or formal factfinding. See Fullilove, 448 U.S. at 502-04 (Powell, J., concurring) (distinguishing legislative from judicial factfinding).

145. 497 U.S. 547 (1990), rev'd, Adarand Constructors, Inc. v. Pena, 515 U.S. 200 (1995). 
which an empirically minded Justice could look in sorting out the politics underlying preference programs. Here, like the 1977 set-aside, power politics, not factfinding, explains Congress's role in defending FCC diversity preferences. Unlike set-asides, however, Congress played a largely reactive role, battling a Reagan FCC hell-bent on eviscerating race preferences. ${ }^{146}$ Prior to 1985 , the question of whether the granting of preferences to minority broadcasters increased the diversity of programming and viewpoint was of little, if any, interest to Congress. ${ }^{147}$ That year, however, the Commission called into question the constitutionality of FCC initiatives that used race preferences to increase program diversity. ${ }^{148}$ Congress, principally through the House Energy and Commerce Committee, responded with a vengeance. Hearings were held castigating all five FCC Commissioners for their failure to honor congressional preferences, and legislation was passed prohibiting the FCC from reexamining its diversity preference initiatives. ${ }^{149}$ That the Congress had never enacted legislation mandating diversity preferences did not matter. It also did not matter that the Commission did not propose repealing their diversity preferences but, instead, proposed engaging in factfinding to see if there was a nexus between race preferences and program diversity. ${ }^{150}$ What did matter is that Congress wanted to preserve these race preferences, and if preventing Commission factfinding was the most expedient way to get to the answer "yes," so be it. ${ }^{151}$

146. Neal Devins, Congress, the FCC, and the Search for the Public Trustee, 56 LAw \& CONTEMP. Probs. 145, 169-80 (Autumn 1993) (detailing President Reagan's opposition to the FCC's "fairness doctrine" on the grounds the doctrine was "antagonistic to the freedom of expression guaranteed by the First Amendment").

147. In 1981 and 1982, however, Congress did find that race discrimination was the cause of minority underrepresentation in broadcasting. These findings were part of a legislative scheme permitting (but not requiring) the FCC to grant licenses through a lottery weighted in favor of minority interests. See H.R. REP. No. 765, 97th Cong., 2d Sess. 43 (1982).

148. In the midst of litigation over the constitutionality of gender preferences, the Commission in September 1986 filed a brief contending that its use of race and gender preferences "conflicts with constitutional standards" and that it needed to sort out whether a nexus existed between its preference scheme and an enhanced diversity of programming. Brief for the Federal Communications Commission on Rehearing En Banc at 22-23, Steele v. FCC, 770 F.2d 1192 (D.C. Cir. 1985).

149. Devins, supra note 146, at 169-80 (detailing this history of race preferences by the FCC, Congress, and the judiciary).

150. Congress, moreover, paid no mind to the fact that it had created the FCC for the very purpose of sorting out how best to advance the public interest on broadcasting-related issues.

151. Unlike legislation mandating diversity preferences (requiring the approval of both houses of Congress and the President), Congress could move more quickly and more efficiently by attaching a limitations rider prohibiting FCC reconsideration to an appropriations bill. See generally Neal E. Devins, Regulation of Government Agencies Through Limitation Riders, 1987 
That Congress did what it did was entirely predictable and, considering the circumstances, quite defensible. At that time, the FCC and the Energy and Commerce Committee were locked in a bitter fight over the propriety of government regulation of broadcasting. ${ }^{152}$ The Commission embraced market-driven solutions, suggesting to Congress that FCC factfinding would simply put into place a preordained conclusion. In other words, Congress was not simply defending civil rights interests; it was defending its own turf. ${ }^{153}$ Further fueling this fire, Energy and Commerce is one of the House's power committees, and its then-Chair, John Dingell (D-MI), was especially interested in exerting influence over government agencies and programs. ${ }^{154}$ Consequently, rather than "'getting bogged down in fruitless debates" over the Commission's legal arguments, "Energy and Commerce members move[d] quickly to fix the problems before them." ${ }^{155}$ In other words, factfinding had no salience to the Committee, for the best way to block the FCC was to block factfinding.

The question of whether Congress, over time, has the institutional incentives to examine the factual premises of diversity preferences still remains. After all, it is to be expected that a Democratic Congress would simultaneously defend its turf and respond to a "fire alarm" triggered by a loyal, powerful constituent. ${ }^{156}$ Over the past six years, however, the Republican leadership in Congress has done its

DUKE L.J. 456 (criticizing Congress's use of the appropriations process for substantive policymaking).

152. In particular, the Committee fought tooth-and-nail to block FCC efforts to repeal the fairness doctrine as well as limitations on the ownership of both newspapers and television stations in the same market. Devins, supra note 146, at 159-61.

153. For this reason, Committee condemnation of the FCC was, to put it mildly, vitriolic. Congressman John Bryant characterized it as "almost pointless" to work with the Commission; Congressman Micky Leland referred to the need to draft "FCC-proof legislation"; and Congressman Edward Markey labeled the FCC reexamination of diversity preferences "a cloudburst in a storm of suspicion and distrust which seems to hover over the Commission." MinorityOwned Broadcast Stations: Hearing Before the Subcomm. on Telecommunications, Consumer Protection, and Finance of the House Comm. on Energy and Commerce, 99th Cong. 31, 20, 22 (1986) [hereinafter Hearings].

154. Mark C. Miller, Congress and the Constitution: A Tale of Two Committees, 3 SETON Hall Const. L.J. 317, 327-36 (1993) (comparing the Energy \& Commerce Committee to the more deliberative Judiciary Committee).

155. Id. at 345 (quoting an interview with a Committee staffer); see also Hearings, supra note 153, at 53-55 (statement of Rep. Al Swift) (bemoaning the FCC's "legalistic gobbledygook" and remaking that "I am not a lawyer, and I am mystified by them all the time").

156. The overwhelming majority of African Americans are Democrats. Moreover, for members of the Congressional Black Caucus, affirmative action ranks at the very top of their legislative agenda. 
best to steer clear of the affirmative action wars. ${ }^{157}$ Worried about "[t]he danger[] that our [party's] aspirations and intentions will be misperceived, dividing our country and harming our party," ${ }^{158}$ Republicans in Congress appear unprepared to take a hard look at the factual premises of various affirmative action programs. ${ }^{159}$

By making the winning of elections and the forging of coalitions their first priority, Republican leaders are simply doing what comes naturally. Today, the costs of affirmative action are spread throughout the nonminority population, so that there is little incentive for voters (or other powerful interests) to rally behind candidates who oppose affirmative action. ${ }^{160}$ In contrast, minority interests in Congress (and their supporters) care passionately about affirmative action. In other words, this may be an issue where "discrete and insular minorities" have disproportionate influence in the political process. ${ }^{161}$ Unlike the 1964 Civil Rights Act, the political forces pushing Con-

157. FCC diversity preferences, for the most part, remain in force. Alan J. Meese, Bakke Betrayed, 63 LAW \& CONTEMP. PROBS. 479, 487-93 (Winter/Spring 2000) (arguing that the Clinton administration misapplied Justice Powell's opinion in Bakke to justify racial preferences in broadcasting). More striking, Congress continues to reauthorize public works set-asides. James Dao, \$200 Billion Bill for Public Works Passed by Congress, N.Y. TIMES, May 23, 1998, at A1.

158. 144 CONG. REC. S1481, 1490 (daily ed. Mar. 6, 1998) (statement of Sen. John McCain). The fact that the Supreme Court, in Adarand Constructors, signaled its skepticism of federal affirmative action has not changed Congress's affirmative action calculus. Neal Devins, The Democracy-Forcing Constitution, 97 MICH. L. REV. 1971, 1985-87 (1999) (discussing Congress's bipartisan support of affirmative action in the wake of Adarand).

159. I do not mean to suggest that affirmative action will not be the subject of congressional inquiries. Congress, for example, did modify set-aside legislation in 1987 to take account of scam firms benefiting under the program. Surface Transportation and Uniform Relocation Assistance Act of 1987, Pub. L. No. 100-17, § 106, 101 Stat. 132, 144 (1987). During the 1990s, moreover, John Ashcroft (R-MO), Charles Canaday (R-FL), and others sponsored hearings questioning the propriety of affirmative action. See, e.g., Unconstitutional Set-Asides: ISTEA's Race-Based Set-Asides After Adarand: Hearing Before the Senate Comm. on the Judiciary, 105th Cong. (1997). And, following the 1994 Republican takeover of Congress, appropriation riders forbidding FCC reconsideration of diversity preferences were not reenacted (a largely symbolic gesture since the Clinton FCC strongly backed these initiatives). Over time, it may be that affirmative action opponents convince a significant portion of the voting public to make preferences a litmus test issue. If that happens, Congress may take a hard look at existing programs. For example, because public works preferences must be reenacted every five years, Congress will have ample opportunity to reconsider the sensibility of these preferences. In this way, by making use of sunset provisions, Congress signals its interest in reexamining the factual premises of legislation. Of course, Congress's willingness to reconsider its handiwork is, ultimately, a by-product of constituent and other interests triggering a "fire alarm." See supra notes 64-67 and accompanying text (describing "fire alarm" triggers), 90-93 and accompanying text (suggesting that sunset provisions encourage Congress's reconsideration of its separation of powers handiwork).

160. In fact, big business typically supports affirmative action, for its costs disproportionately fall on smaller, less powerful business interests.

161. For the definitive treatment of this issue, see generally Bruce A. Ackerman, Beyond Carolene Products, 98 HARV. L. REV. 713 (1985). 
gress to take factfinding seriously have not emerged on affirmative action. $^{162}$

It is for this very reason that the Supreme Court erred in Metro Broadcasting. By employing intermediate scrutiny, a highly malleable fact-dependent standard of review, the Justices placed great emphasis on "Congress' institutional competence as the National Legislature" and, with it, the "appropriate deference [owed] to Congress." way, the Justices paved the way for Congress to see race preferences as a type of spoils system, something that could be used to respond to interest group pressures, rather than something that serves the public interest. An empirically minded Court, in contrast, would have wanted to signal Congress that it would look skeptically at legislative factfinding intended to prop up the policy preferences of special interests. For example, by employing strict scrutiny review, ${ }^{164}$ the Court could declare-as a matter of law-that certain governmental purposes are insufficient to support race preferences, ${ }^{165}$ thus allowing the Court to police race preferences without absorbing the legitimacy costs of second-guessing legislative factfinding. ${ }^{166}$

162. For similar reasons, affirmative action can be distinguished from voting rights legislation, especially the 1965 Voting Rights Act, 79 Stat. 437 (1965). To overcome southern resistance to the 1965 Act, Congress needed a strong factual record to support its handiwork. GRAHAM, supra note 120, at 162-73 (detailing the history of the 1965 Act). By 1982, when Congress amended the statute, things had changed. In part, Congress wanted to distance itself from Reagan administration efforts to grant tax breaks to racist schools. Also in part, no set of powerful interests stood in the way of the Leadership Conference on Civil Rights, an amalgamation of 165 civil rights groups. See generally ABIGAIL M. THERnSTROM, WHOSE VOTES COUNT? 79136 (1987) (describing the politics of legislative passage in the House and the liberal power in a conservative Senate). Consequently, when the House held hearings on the bill, no witnesses opposed to the bill were called to counter representatives from numerous civil rights groups. Id. at 83-86 (quoting Thomas Boyd, Republican minority counsel, as saying "the only critics were supposed to come from us, and we didn't want to call them because we weren't really critical of the act, only certain provisions, and didn't want to be perceived as against the act").

163. Metro Broad., Inc. v. FCC, 497 U.S. 547, 563 (1990).

164. In Adarand Constructors, Inc. v. Pena, 515 U.S. 200 (1995), the Supreme Court rejected the "lenient standard" of Metro Broadcasting, replacing it with strict scrutiny review. Id. at 236. In so doing, however, the Court said nothing at all about the concerns of legislative factfinding and special-interest capture that animate this Essay.

165. In Wygant v. Jackson Board of Education, 476 U.S. 267 (1986), for example, the Court concluded that — as a matter of law—a school board did not have a compelling interest either in remedying societal discrimination or in providing minority role models for its minority students. Id. at 276 .

166. The Justices, of course, could also embrace a hard rule, namely, that any and all race preferences are unconstitutional as a matter of law. This type of rule, however, would deny Congress the power to demonstrate-through factfinding in the public interest- the necessity of some race preference programs. 


\section{Summary}

The question of whether courts or lawmakers will do a better job of uncovering social facts is highly contextual. Congress is better positioned to find social facts, but it is far from clear that Congress has the incentives to make full use of its superior factfinding resources. In particular, as the above discussion makes clear, Congress does what it needs to do to advance the interests of voters, interest groups, and party leaders. ${ }^{167}$ Factfinding sometimes fits into this equation, but often it does not. It is for this very reason that the Supreme Court must exercise great care before embracing fact-dependent standards of review. In particular, unless the Justices are willing to overturn these decisions, ${ }^{168}$ the selection of a fact-dependent standard may well limit the Court in its ability to check Congress from rewarding special interests. If the checking of special interests is a principal objective of the Constitution and, with it, judicial review of legislative decisionmaking, the Court should limit its embrace of fact-dependent standards of review to those circumstances where Congress has the incentives to serve the public interest, and, by extension, to get the facts right in the first instance or to correct its mistakes over time.

\section{CONCLUSION: AN EMPIRICALLY INFORMED CONSTITUTIONAL JURISPRUDENCE?}

The possibility of an empirically informed jurisprudence is premised on the belief that either Congress or the Supreme Court has both the willingness and the capacity to understand social facts. By calling attention to significant roadblocks standing in the way of both congressional and judicial factfinding, however, this Essay underscores how problematic and difficult it is for the Court to craft stan-

167. I am not suggesting that Congress is not at all motivated by the public interest. But Congress's understanding of the public interest is shaped by these constituents.

168. Sometimes, the costs of overturning a decision are so high that the Court will almost certainly adhere to a decision whose factual premises no longer seem correct. Consider, for example, Morrison v. Olson, 487 U.S. 654 (1988). Here, there was little prospect of the Court overturning itself and declaring the Independent Counsel statute unconstitutional. In particular, since Congress and the President have to sign off on the statute every five years, the Justices would find it especially difficult to say that, contrary to their holding in Morrison, the Independent Counsel statute disrupts the balance of powers. Not only would such a declaration fly in the face of the statute's continuing approval by Congress and the White House, the occasion in which the Court would consider overruling the statute would, by definition, be politically charged. After all, Independent Counsel investigations are limited to the President and other high ranking executive officials. For further discussion, see infra notes 180-81 and accompanying text. 
dards of review that take into account the comparative strengths and weaknesses of congressional and judicial factfinding. In sorting out how the Supreme Court should navigate its way around these roadblocks, I have suggested that the Justices should take factfinding seriously and adopt fact-dependent standards only when Congress has the institutional incentives to accurately perform this function. Moreover, as I will now argue, the Court should look at ways it can facilitate factfinding by both Congress and itself.

In this concluding part, additional details about the workings of this incentives model will be revealed. Before turning to some of the things that an empirically minded Court can do, let me dismiss some untenable possibilities, namely: a prophylactic rule favoring either Congress or the Court, due process in lawmaking, and judicial minimalism. For quite obvious reasons, there is nothing to commend a rule whereby the Court assumes that Congress takes factfinding seriously and, consequently, any and all legislative enactments are empirically grounded (whether or not Congress held hearings, made findings, etc.). ${ }^{169}$ Unless and until Congress has reason to make good use of its superior factfinding skills, it is hard to see how such a rule would accomplish anything-other than to further diminish Congress's interest in factfinding.

A prophylactic rule favoring the Court is at least as untenable. To embrace a standard of review that would make it, not Congress, supreme in the finding of social facts, the Justices would have to show both that Congress cannot perform its constitutional duties and that the Court is well-positioned to assume the role of factfinding czar. ${ }^{170}$ Inherent limits in judicial factfinding, the tendency for Justices to

169. Outside of deferential rational basis review, the Court, on occasion, employs this model. E.g., Turner Broad. Sys., Inc. v. FCC, 520 U.S. 180, 199-202 (1997) ("Though the dissent criticizes our reliance on evidence provided to Congress ... that argument displays a lack of regard for Congress' factfinding function.... The Constitution gives to Congress the role of weighing conflicting evidence in the legislative process."); Metro Broad., Inc. v. FCC, 497 U.S. 547,572 (1990) ("We would be remiss ... if we ignored the long history of congressional support for these policies ... because ... Congress has consistently recognized the barriers encountered by minorities ....”); Fullilove v. Klutznick, 448 U.S. 448, 502-03 (1980) (Powell, J., concurring) ("Congress is not an adjudicatory body called upon to resolve specific disputes between competing adversaries. Its constitutional role is to be representative rather than impartial, to make policy rather than apply settled principles of law.").

170. In other words, "justifying an expansion of judicial review requires more than a demonstration that the political process often produces defective outcomes. It requires a demonstration that expanding the realm of judicial decisionmaking would reduce the possibility of defective outcomes." Einer R. Elhauge, Does Interest Group Theory Justify More Intrusive Judicial Review?, 101 YALE L.J. 31, 67; see also KOMESAR, supra note 68, at 138-50 (comparing courts and lawmakers). 
follow the lead of the political party that appoints them, and the need for the Court to secure support for its rulings from elected officials stand in the way of such a radical departure from the traditionalist view that-consistent with the separation of powers-deference is owed Congress's factfinding.

Due process in lawmaking stands on much firmer footing, for it is largely grounded in the real world. Recognizing Congress's disinterest in exploring the empirical foundations of its handiwork, due process in lawmaking is seen as a way of encouraging Congress to take factfinding seriously. Courts, for example, can make use of a constitutional interpretive canon that would condition judicial approval of legislation to the procedures that Congress employs when enacting a bill. ${ }^{171}$ By encouraging Congress to find facts, hold hearings, and formally tie their factfinding to the evidence they gather, due process in lawmaking stands as a means of ensuring that Congress is taking factfinding seriously.

Two insurmountable hurdles, however, stand in the way of such an approach. First, if Congress is acting at the behest of special interests, any such factfinding is likely to be boilerplate. Committee chairs can ask members of their staffs or the bill's interest group sponsors to sort out the measure's factual underpinnings. And while "judges on review can ensure that factfinding be based on empirical evidence, enterprising staffers should be able to surmount any such obstacle." ${ }^{172}$ Second, courts cannot set manageable standards to overcome the problem of boilerplate factfinding. ${ }^{173}$ How, for example, can a court

171. Frickey, supra note 21, at 710-11 (focusing on how Congress's factual findings can respond to judicial concerns and noting that even extensive social facts cannot overcome a judicial limitation on congressional power, so that the Court must strike down ultra vires legislation or modify the standard for assessing legislation); Friedman, supra note 111, at 758 (agreeing with Frickey that after Lopez, Congress should articulate the relevant judicial standard and then develop facts to show that the legislation in question satisfies that standard).

172. Krent, supra note 119, at 735 (noting that it is feasible for Congress to demonstrate the factual underpinnings of federal regulation to courts' satisfaction by assigning staff to research issues and provide empirical evidence on which Congress may base its factfinding); supra notes 56-59 and accompanying text (noting that staffers may pad legislative history and, consequently, courts should be cautious about looking at such history in discerning legislative intent); see also Vicki L. Jackson, Federalism and the Uses and Limits of Law: Printz and Principle?, 111 HARV. L. REV. 2180, 2240 (1998) (suggesting that the Court impose upon Congress a "process-based "clear evidence/clear statement" requirement when Congress regulates in ways "not obviously within an enumerated power").

173. Likewise, courts are constrained in that Congress sometimes finds facts without creating a record. Justice Lewis Powell put it this way:

Congress [unlike a court or administrative agency] has no responsibility to confine its vision to the facts and evidence adduced by particular parties. Instead, its special attribute as a legislative body lies in its broader mission to investigate and consider all 
tell if a witness list at a hearing is skewed, or whether a bill is fairly debated? How can it tell whether members of Congress are reasonable in their assessment of social science research, the credibility of witnesses, so on and so forth? The answers to these questions are value-laden, requiring the court to substitute its judgment for that of Congress. In other words, due process applied to lawmaking cannot be penetrating without undermining its principal virtue, that is, avoiding the pitfalls of judge-made lawmaking.

Judicial minimalism offers a way around these problems but creates new problems of its own. By issuing minimalist opinions that would allow the Justices to revisit an issue without overruling themselves, the Court need not reach a definitive judgment on the quality of congressional factfinding. ${ }^{174}$ Relatedly, by issuing a minimalist decision, the Court can also sidestep the question of whether it should substitute its factfinding for that of Congress. The problem, however, is that, over time, a minimalist Court will never get around to settling on a standard of review either validating or minimizing congressional factfinding. ${ }^{175}$ In this way, a minimalist Court, ultimately, is unconcerned with Congress's interest in getting the facts right.

What then can the Supreme Court do both in assessing the quality of legislative factfinding and in encouraging Congress to take factfinding more seriously? ${ }^{176}$ In particular, how can the Justices put into effect the incentives model that this Essay champions? To start with, rather than speculate on Congress's interest in factfinding (and, more generally, whether Congress is acting in the public interest, not simply

facts and opinions that may be relevant to the resolution of an issue.

Fullilove, 448 U.S. at 502-03 (Powell, J., concurring). In other words, due process in lawmaking does not take into account how legislative and adjudicatory factfinding are inherently different.

174. Cass R. Sunstein, One Case at a Time: Judicial Minimalism on the Supreme COURT 4-5 (1999). Limitations in judicial factfinding (including the Court's power to assess legislative factfinding) are but one ingredient in the mix of factors that Sunstein cites in support of his proposal.

175. Moreover, judicial minimalism undermines the Court's power to speak forcefully about the Constitution's meaning and, as such, denies the Court a coequal role in shaping constitutional values. Devins, supra note 158, at 1990-91; see also Christopher J. Peters, Assessing the New Judicial Minimalism, 100 Colum. L. REv. 1454, 1458 (2000) (rejecting current arguments for judicial minimalism, which focus on the judiciary's role in bolstering the accountability of other political institutions, in favor of a "juricentric minimalism" that emphasizes the legitimacy of the adjudicative process and the judiciary's ability to protect individual rights).

176. On the importance of devising strategies that encourage Congress to perform its institutional duties, see John Hart Ely, Another Such Victory: Constitutional Theory and Practice in a World Where Courts Are No Different from Legislatures, 77 VA. L. REV. 833, 879 (1991) (contending that "[h]elping devise such judicial Congress-prodding doctrines thus seems to me the most productive use that can currently be made of a constitutional scholar's time"). 
promoting special interests), ${ }^{177}$ the Justices can make use of the "passive virtues," that is, procedural and jurisdictional delays that provide "a time lag between legislation and adjudication." ${ }^{178}$ In so doing, the Court (as well as the litigants and amici who inform the Justices through their filings) can gain a better appreciation of the relevant social facts. By looking to Congress's interest in overseeing the implementation of the law, its decisionmaking on related issues, and the decisionmaking of several lower courts, the Court can better sort out, among other things, the trustworthiness of Congress's factfinding. ${ }^{179}$ By improving its understanding of Congress and, more generally, the social facts of the dispute before it, the Court is less apt to box itself into a corner. Specifically, since the legitimacy costs of overruling a decision are significant, the Court may adhere to a premature, illinformed decision. ${ }^{180}$ For this reason, it is critically important that the Court not get it wrong the first time around. Agenda control, while hardly a guarantee, can help the Court understand both Congress's interest in getting the facts right and the factual premises of its decisionmaking.

Sometimes, however, the Court cannot make use of agenda control to delay a decision. In the Independent Counsel case, for example, a lower court finding that the statute was unconstitutional made it impractical for the Court to refuse to hear the case. ${ }^{181}$ At the same time, rather than speak definitively about the statute's constitutionality, the Justices could have decided the case narrowly, upholding the statute while leaving open the possibility that the Court could revisit

177. There may be occasions, of course, where Congress is acting in the public interest but is nevertheless uninterested in factfinding. When that happens, an empirically minded Court should hesitate before embracing fact-dependent standards of review.

178. Alexander M. Bickel, The Least Dangerous Branch: The Supreme Court AT THE BAR OF POLITICS 116 (1962) (advocating that restraint operate at the point of access, before a case reaches the decision stage).

179. For a somewhat analogous argument, see Michael C. Dorf, Foreword: The Limits of Socratic Deliberation, 112 HARV. L. REV. 4, 65 (1998) (defending "provisional adjudication," in part, because delaying strategies allow the Supreme Court "the benefit of [deciding cases against the backdrop of] well-reasoned opinions by the federal courts of appeals and perhaps the state courts of last resort").

180. See supra notes 25-26, 111-33 (discussing the difficulties of overruling the "affecting commerce" standard). For a thoughtful treatment of how path-dependency in the law encourages Justices to make use of standing, denials of certiorari, and other avoidance doctrines, see Maxwell L. Stearns, Constitutional Process: A Social Choice Analysis of SUPREME COURT DECISION MAKING 157-80, 310 (2000).

181. In re Sealed Case, 838 F.2d 476 (D.C. Cir. 1988). Had the Justices refused to hear the case, the statute would have been effectively voided in the D.C. Circuit, the very circuit in which a three-judge panel appoints independent counsels. 
the issue in another case. By saying as little as possible in the first instance, this type of delaying strategy, unlike judicial minimalism, looks to the Court-perhaps in a dialogue with the political branches - to issue a broad ruling about the underlying constitutional issue. $^{182}$

Over time, of course, the Justices must sort out whether to embrace standards of review that either defer to, or are skeptical of, congressional factfinding. ${ }^{183}$ On some issues, like those implicating separation of powers concerns, Congress (at least sometimes) may well have the institutional incentives to moderate its handiwork in order to preserve the balance of powers. ${ }^{184}$ On other issues, like those dealing with Congress's federalism-implicated powers, this investigation may reveal that Congress's desire to do that which is politically popular is far stronger than its desire to self-police its powers under either the Commerce Clause or Section 5 of the Fourteenth Amendment. ${ }^{185}$ By observing Congress this way, the Court can sort out whether Congress has the institutional incentives to take factfinding seriously. ${ }^{186}$ Among other things, the Court can see how Congress makes use of sunset provisions or other mechanisms that ensure that lawmakers do not lose sight of the issue and/or shift the burden of in-

182. Christopher J. Peters, in a thoughtful review of the ever-burgeoning literature on judicial minimalism, refers to this type of delaying strategy as "procedural minimalism." Peters, $s u$ pra note 175, at 1513-20 (defending procedural minimalism as consistent with the Court's duty to speak to questions of rights).

183. In addition to factfinding, the Justices will also take into account theories of interpretation, political context, etc. Consequently, the Court's view on congressional factfinding may, ultimately, be trumped by other concerns.

184. See supra notes $72-97$ and accompanying text.

185. See supra notes 100-33 and accompanying text. Perhaps for this reason, the Court, in United States v. Morrison, made use of a stringent rule that made Congress's voluminous factfinding irrelevant. 529 U.S. 598, 614 (2000) ("[The Act] is supported by numerous findings regarding the serious impact that gender-motivated violence has on victims and their families .... But the existence of congressional findings is not sufficient, by itself, to sustain the constitutionality of Commerce Clause legislation."). Specifically, the Court may have concluded that the only way to limit Congress was to deem certain types of regulation outside of Congress's Commerce Clause authority.

186. On occasion, the Court does just that. In Bush v. Lucas, 462 U.S. 367 (1983), for example, the Court deferred to Congress's choice of remedial schemes for alleged violations of the First Amendment rights of government workers. Id. at 388-90 ("Congress is in a far better position than a court to evaluate the impact of a new species of litigation between federal employees on the efficiency of the civil service."). A key aspect of the Court's reasoning was its belief that "Congress has a special interest in informing itself about... the Executive Branch" and that "[i]n the past it has demonstrated its awareness ... that supervisors might improperly attempt to curtail their subordinates' freedom of expression." Id. at 389. For this reason, the Court deferred to "Congress' ability to make an evenhanded assessment of the desirability" of providing remedies for federal employees sanctioned for expressing controversial views. Id. 
ertia to constituent and other interests that support reenactment of the law. ${ }^{187}$

Operating within the Washington, D.C., beltway, moreover, the Court can take into account the circumstances surrounding the enactment of legislation. In particular, as was true with the 1964 Civil Rights Act, the Court can see whether competing interests within Congress put pressure on the institution to take factfinding seriously. ${ }^{188}$ Alternatively, it may be that logrolling or the absence of disagreement within Congress produces legislation, like the public works set-asides, the RFRA, and the GFSZA, where factfinding is simply beside the point. ${ }^{189}$

Needless to say, these inquiries are indeterminate and, ultimately, value-laden. ${ }^{190}$ Nevertheless, by thinking about the incentives within Congress and observing how Congress acts on those incentives, this type of agenda control can facilitate constructive constitutional dialogues between Congress and the Court. Consider again the Independent Counsel statute. When Congress enacted this statute, no one could predict whether the Attorney General, in fact, would maintain meaningful control of independent counsel investigations. Why then should the Court assume either the best or the worst about congressional factfinding ? $^{191}$ Instead, by making use of certiorari denials and other delaying strategies, ${ }^{192}$ the Court can wait to see both how the statute works and how Congress responds to the statute's implementation. Courts simply "do not need to commit themselves so com-

187. Congress made use of sunset provisions with the line-item veto, the Independent Counsel, and public works set-asides. See supra notes 72-97, 134-55 and accompanying text. Unfunded mandates legislation, moreover, contains a procedural device allowing any member to force floor consideration of states' rights concerns. See supra note 124.

188. See supra notes 120-24 and accompanying text.

189. See supra notes 17-18,111-21, 135-39 and accompanying text.

190. Consider, for example, federalism. While I conclude that Congress cannot be trusted to self-police itself, several scholars have reached the opposite conclusion. See supra note 104.

191. Dissenting in Morrison v. Olson, Justice Antonin Scalia assumed the worst about congressional factfinding, substituting his understanding of how the statute would work for that of Congress. 487 U.S. 654, 701-03 (1988) (Scalia, J., dissenting) (“Although the Court's opinion asserts that the Attorney General had 'no duty to comply with the [congressional] request' ... that is not entirely accurate. He had a duty to comply unless he could conclude that there were 'no reasonable grounds to believe,' ... that 'further investigation' was warranted."). In sharp contrast, the Court's majority opinion effectively assumed the best about congressional factfinding, holding that the Attorney General maintained meaningful control of independent counsel investigations. $I d$. at $692-93,696$ ("[T] he Attorney General retains the power to remove the counsel for 'good cause' .... No independent counsel may be appointed without a specific request by the Attorney General .... The Act thus gives the Executive a degree of control over the power to initiate an investigation by the independent counsel.").

192. See supra notes $98-99$ and accompanying text. 
pletely and all at once. They can in cases of doubt use ... techniques that encourage legislatures, scholars, and even the public to engage them in dialogue and give back data stronger then hunches." deed, by giving Congress breathing room in the first instance, the Court creates incentives for Congress to demonstrate its bona fides by paying attention to the law's implementation. ${ }^{194}$

But is it possible to have an empirically informed constitutional jurisprudence? After all, if the courts cannot and Congress will not take factfinding seriously, there is little reason to contemplate crafting standards of review that take factfinding into account. In attempting to answer this question, I have advanced a decisionmaking model that takes into account the circumstances in which Congress has the incentives to take factfinding seriously.

Beyond identifying whether Congress or the Court is likely to do a better job at sorting out the underlying social facts (something of interest to Justices thinking about the consequences of choosing a factdependent standard or a fact-insensitive rule), this incentives model also embraces a normative theory of constitutional interpretation, that is, that one of the principal purposes of judicial review is to guard against special-interest legislation. Specifically, in advancing the public interest, the Justices should craft standards of review that take into account Congress's interest in getting the facts right, at least over time. When it comes to some type of legislation, e.g., separation of powers, there is enough friction between the branches that Congress will usually produce handiwork that reflects constitutional concerns. In other contexts, like racial preferences or federalism, there is far less reason to be confident of Congress's ability to incorporate equality or federalism values when legislating.

193. Guido Calabresi, A Common Law for the Age of Statutes 267 n.3 (1982). In the case of the Independent Counsel, a lower court finding that the statute was unconstitutional forced the Supreme Court to hear the case. See supra notes 85-87 and accompanying text. With that said, rather than uphold the statute without qualifications, the Court could have issued a narrower opinion, one that left open the question of whether the President's control of the executive branch might be undermined by the statute.

194. Furthermore, by not committing itself to a particular vision of the facts (and, accordingly, to Congress's capacity as factfinder), the Court is not limited by a precedent whose factual premises may prove incorrect. For similar reasons, the Court ought to be cautious about embracing a rule that defers to any and all congressional factfinding. For example, in Metro Broadcasting, Inc. v. FCC, 497 U.S. 547 (1990), the Court was wrong to assume that Congress could be trusted to sort out whether a nexus exists between programmatic diversity and a broadcaster's race. Id. at 578-84 ("Congress and the Commission have determined that ... there is a nexus between minority ownership and broadcasting diversity .... [W]e believe it a legitimate inference for Congress and the Commission to draw that as more minorities gain ownership and policymaking roles in the media, varying perspectives will be more fairly represented ...."). 
I do not pretend that this model is fail-proof. The question of whether Congress has the incentives to serve the public interest, not special interests, is value-laden and indeterminate. With that said, failings in this model call attention to how difficult it is for the Court to navigate the law-fact divide. More to the point, by calling attention to how difficult it is for courts to check Congress when employing fact-dependent standards, this Essay sends a cautionary note to the Court. In particular, while not disavowing such fact-dependent standards, this Essay suggests that Justices contemplating the adoption of standards of review that give Congress the upper hand should have confidence in congressional factfinding, and/or should want Congress to control the issue, and/or should make use of some interpretive theory that suggests that the Court should play a de minimis role. ${ }^{195}$

My proposal, as the title of this Essay suggests, is a preliminary inquiry into ways that the Court can better take factfinding into account when crafting standards of review. Whatever one thinks of the incentives model that I embrace, the enterprise of getting the Court to think about how it and Congress finds facts as well as ways to improve the quality of factfinding is critically important. If nothing else, I hope this Essay is a small step in encouraging the Court to take factfinding into account when crafting standards of review. ${ }^{196}$

195. By sending such a cautionary note about fact-dependent standards, this Essay provides some support for theorists who argue that the Court should, as a general matter, employ factinsensitive rules. E.g., CASS R. Sunstein, Legal Reasoning and Political Conflict 12135 (1996) (noting the drawbacks of rules); Larry Alexander, "With Me, It's All Er Nuthin'”: Formalism in Law and Morality, 66 U. CHI. L. REV. 530, 531 (1999) (defending rules); Antonin Scalia, The Rule of Law as a Law of Rules, 56 U. CHI. L. REV. 1175, 1176 (1989) (same); Kathleen M. Sullivan, Foreword: The Justices of Rules and Standards, 106 HARV. L. REV. 22, 62-69 (1992) (detailing arguments for rules and standards). At the same time, by suggesting that factdependent standards sometimes be used, this Essay charts a middle ground in this debate.

196. Some of the times, of course, the Court will employ standards of review that place little emphasis on factfinding. This may be because of the theories of interpretation that the Justices employ, the case's political setting, etc. When this happens, complaints that the Court is not paying sufficient attention to the underlying facts may, ultimately, be little more than complaints that the Court (by not finding those social facts relevant) is making use of the wrong theory of interpretation. Merritt, supra note 5, at 1288 (arguing that, in calling for some empiricism in the law, Judge Posner "disagrees with the Court's theory of the Equal Protection Clause-not with its understanding of the facts"). 